\title{
Thermokarst lake waters across the permafrost zones of western Siberia
}

\author{
R. M. Manasypov ${ }^{1,2}$, O. S. Pokrovsky ${ }^{1,2}$, S. N. Kirpotin ${ }^{2}$, and L. S. Shirokova ${ }^{1,3}$ \\ ${ }^{1}$ Geoscience and Environnement Toulouse, UMR5563 CNRS, Université de Toulouse, 14 avenue Edouard Belin, \\ 31400, France \\ ${ }^{2}$ Tomsk State University, 634050, Tomsk, 36 Lenin av., Russia \\ ${ }^{3}$ Institute of Ecological Problems of the North UroRAS, 163061, Arkhangelsk, Nab. Severnoj Dviny, 23, Russia \\ Correspondence to: O. S. Pokrovsky (oleg@get.obs-mip.fr)
}

Received: 9 September 2013 - Published in The Cryosphere Discuss.: 5 November 2013

Revised: 30 May 2014 - Accepted: 7 June 2014 - Published: 11 July 2014

\begin{abstract}
This work describes the hydrochemical composition of thermokarst lake and pond ecosystems, which are observed in various sizes with different degrees of permafrost influence and are located in the northern part of western Siberia within the continuous and discontinuous permafrost zones. We analysed the elemental chemical composition of the lake waters relative to their surface areas (from 10 to $10^{6} \mathrm{~m}^{2}$ ) and described the elemental composition of the thermokarst water body ecosystems in detail. We revealed significant correlations between the $\mathrm{Fe}, \mathrm{Al}$, dissolved organic carbon (DOC) and various chemical elements across a latitude gradient covering approximately $900 \mathrm{~km}$. Several groups of chemical elements that reflect the evolution of the studied water bodies were distinguished. Combining the data for the studied latitude profile with the information available in the current literature demonstrated that the average dissolved elemental concentrations in lakes with different areas depend specifically on the latitudinal position, which is presumably linked to (1) the elements leached from frozen peat, which is the main source of the solutes in thermokarst lakes, (2) marine atmospheric aerosol depositions, particularly near the sea border and (3) short-range industrial pollution by certain metals from the largest Russian Arctic smelter. We discuss the evolution of the chemical compositions observed in thermokarst lakes during their formation and drainage and predict the effect that changing the permafrost regime in western Siberia has on the hydrochemistry of the lakes.
\end{abstract}

\section{Introduction}

The wetland ecosystems of the sub-Arctic region of western Siberia act as unique natural indicators of climate change because these ecosystems are the most sensitive toward changes in the natural environment. The primary reason for this sensitivity is the presence of frozen peat deposits, which become highly unstable during climate warming scenarios and thermokarst development (Kirpotin et al., 1995, 2003, 2008; Kirpotin and Vorobiov, 1999; Kravtsova and Bystrova, 2009; Callaghan et al., 1999; Muldiyarov et al., 2001). Until recently, most studies on thermokarst, specifically the thawing of ice-rich permafrost or the melting of massive ground ice (i.e. Jorgenson et al., 2008), have been performed in Canada, Alaska, Mongolia, China, Antarctica and eastern Siberia (see Kokelj and Jorgenson (2013) for a review and Boike et al. (2013) for a description of the Lena River Delta Observatory). However, relatively little attention has been paid to the vast area of the western Siberian lowlands (WSL), where the largest resources of potentially unstable frozen peat are concentrated. Most studies in this region were related to greenhouse gases, particularly $\mathrm{CH}_{4}$, and their release to the atmosphere from the surface of the thermokarst lakes (Walter et al., 2006, 2008) and other forms of permafrost thaw (Walter Anthony et al., 2012).

The frozen peatlands in the northern portion of the WSL contain palsa-like raised bog complexes that are subjected to permafrost thaw and lake formation. Thermokarst lake formation is a dominant mode of permafrost degradation involving a surface disturbance, melting ground ice, surface subsidence and water impoundment (Grosse et al., 2013; 
Dugan et al., 2012). The concept of the cyclic development of raised bog complexes was suggested by Scandinavian researchers (Matthews et al., 1997; Sollid and Sorbel, 1998) and was developed further for western Siberia several years ago (Kirpotin et al., 2007, 2008, 2011). Briefly, the process of soil thaw begins from permafrost subsidence at the flat bog with the formation of a soil depression, which is an "embryo" of the lake that continues growing until it achieves the kilometre-sized mature stage. At this stage, the lake may be drained after connecting to another water body or to a hydrological network, forming a drained lake or khasyrey. On the dry bottom of khasyreys, the frozen peat bogs begin to thaw, initiating a new thermokarst lake cycle. Remote sensing techniques demonstrate that in western Siberia the dominant processes are currently the increasing number of small thermokarst lakes in the north and the drainage of large lakes to the river network south of the cryolithozone (Kirpotin et al., 2009a; Bryskina and Kirpotin, 2012; Polishchuk et al., 2014).

The thermokarst lakes of western Siberia are understudied; only a few reports have revealed their hydrochemical composition (Savchenko, 1992; Leonova, 2004; Leonova et al., 2005; Moskovchenko, 2010; Pokrovsky et al., 2011, 2013; Savichev et al., 2011; Manasypov et al., 2012; Shirokova et al., 2013). Within the northern border of the discontinuous permafrost, a few thermokarst lakes and ponds near Novyi Urengoy have been investigated (Shirokova et al., 2009; Audry et al., 2011). The primary results of the previous studies of the major and trace elements in the thermokarst lakes in western Siberia are as follows: (1) a common source of materials, such as soil peat or deep silicate rocks, was established for $\mathrm{Ca}, \mathrm{Si}, \mathrm{Al}, \mathrm{Ti}, \mathrm{Zr}, \mathrm{Hf}, \mathrm{Pb}$ and $\mathrm{U}$ (Pokrovsky et al., 2011); (2) the element-specific mobilisation mechanisms were identified through the organic and organomineral colloids, which are particularly visible for $\mathrm{Fe}, \mathrm{Al}$, trivalent and tetravalent hydrolysates (Shirokova et al., 2013); (3) the processes of biological uptake and release $(\mathrm{Zn}, \mathrm{Mn}, \mathrm{Co}, \mathrm{Mo}, \mathrm{Cu}$, $\mathrm{Si}, \mathrm{P}, \mathrm{Cd}$ ) were characterised in the water column and are particularly pronounced during hot summer periods (Pokrovsky et al., 2013); (4) the sedimentation of solid phases containing metals and metalloids in the sediments and the diffusional flux to the bottom layers were demonstrated (Audry et al., 2011).

Frey et al. (2007) investigated a set of large and small rivers and streams located from $55^{\circ} \mathrm{N}$ to $69^{\circ} \mathrm{N}$ in the West Siberian Plain, revealing a distinct change in the stream water hydrochemistry from the permafrost-free zone, where the rivers are fed by groundwater, to the permafrost-bearing zone, where the primary feeding is due to element leaching from the peat in the surface (unfrozen) soil horizons. However, no significant gradient was found in the stream water chemical composition within the permafrost zone northward of $61^{\circ} \mathrm{N}$. The thermokarst lakes of this study, which are located exclusively within the permafrost-bearing zone, may offer a new dimension when evaluating the effect of the permafrost on the surface water hydrochemistry. Indeed, the lakes integrate multiple processes better at the landscape level and have significantly higher spatial resolution because they have much smaller watershed areas than rivers and streams. Toward this purpose, the northern part of the western Siberian Plain presents an ideal case study given the following characteristics: (1) contrasting permafrost coverage, ranging from sporadic to continuous, (2) a homogeneous geomorphological/orographic context; (3) high homogeneity in the peat soil and underlying Neocene clays and sands over a significant latitudinal profile and (4) relatively easy access to study sites through the existing road infrastructure, which is linked to the oil and gas industry. The major goal of the present study was to extend the lake sampling across different permafrost zones from the sporadic/discontinuous permafrost in the south to the continuous permafrost and coastal Arctic regions, revealing the primary features of the landscape and latitudinal control over the hydrochemistry of the thermokarst water bodies. This work also attempts to quantify the average dissolved organic carbon (DOC), major and trace element (TE) concentrations and stocks in the thermokarst lakes across the permafrost-bearing zone of western Siberia and to predict the magnitude of any possible changes in these parameters through the "substitute space for time" approach (Frey et al., 2007).

Based on recently collected data, we study the chemical composition of the thermokarst lakes and ponds along a $900 \mathrm{~km}$ gradient of climate, vegetation and permafrost coverage to answer the following questions:

1. Do the variations in the chemical composition of lake water chemical composition as a function of the surface area of the lake in the continuous permafrost zone follow the trends established in the discontinuous and sporadic zone?

2. Is there a latitude gradient for the DOC and TE concentrations in thermokarst lakes similar in size (subsidence, ponds, large lakes and drained lakes)?

3. Is it possible to establish a functional dependence between the dissolved lake water component concentration and the lake surface area and to extrapolate these relationships for the entire territory of the western Siberia permafrost zone?

\section{Study sites and methods}

The studied region is located within a tundra and foresttundra zone of the northern part of the western Siberian wetlands, within the discontinuous and continuous permafrost zones (Fig. 1). This region is dominated by small thermokarst lakes less than $1 \mathrm{~km}^{2}$ in surface area; their total surface area is estimated at $44000 \mathrm{~km}^{2}$ (Rikhter, 1963; Domaniczkii et al., 1971; Ivanov and Novikov, 1976; Kravtsova and Bystrova, 


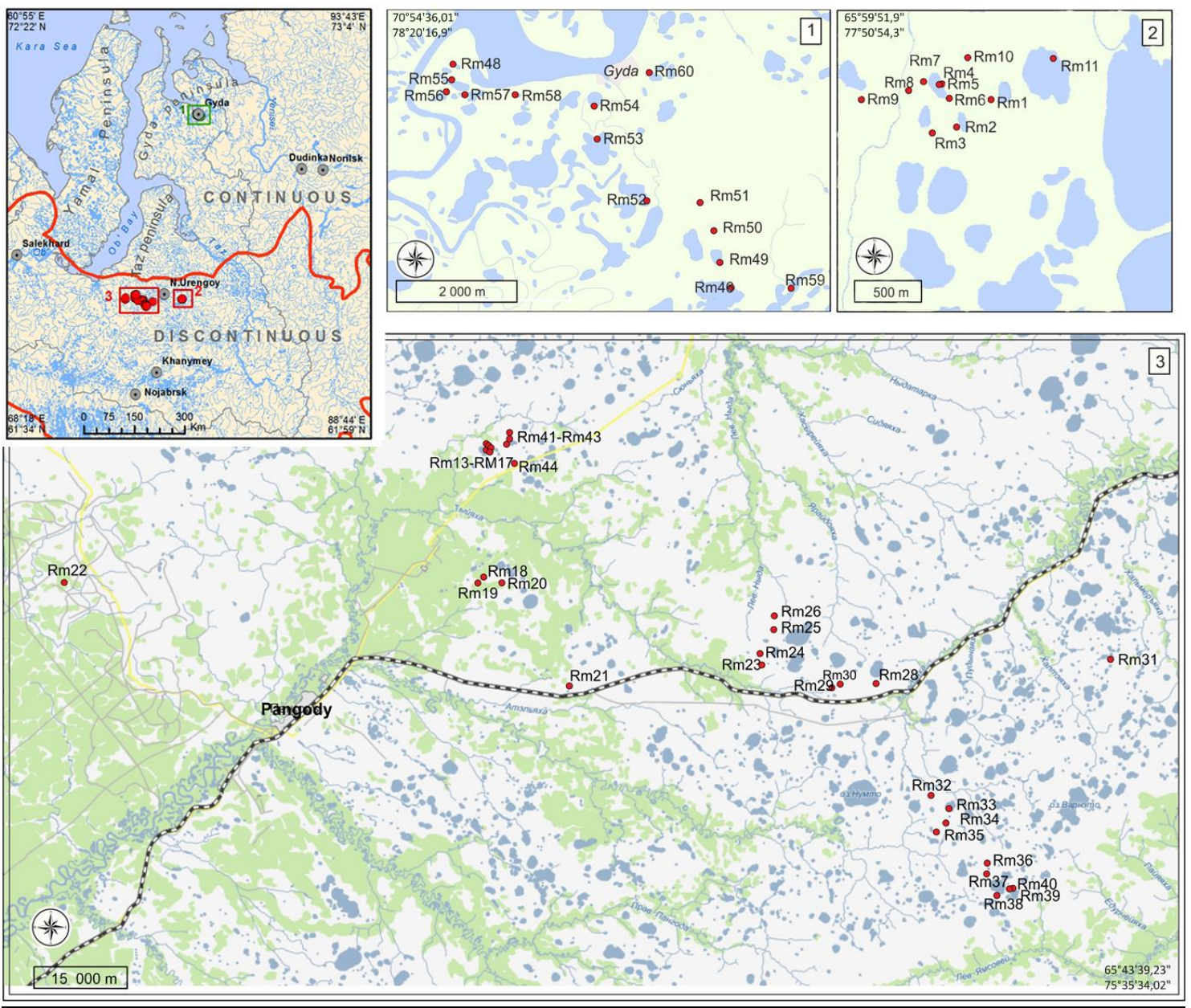

Figure 1. Map of the studied region. Grey dots represent the towns. Position of permafrost distribution is according to Brown et al. (1997). Sites 1, 2 and 3 correspond to Gyda, Novyi Urengoy and Pangody respectively. They comprise the continental zone of discontinuous permafrost, including the coastal zone, around the village of Gyda within the zone of continuous permafrost sampled in August 2011; the east of the Novyi Urengoy region in August 2011; and the district of Pangody (Yamalo-Nenetsk region), west of the Novyi Urengoy region in August 2010, respectively.

2009). The investigated water bodies are mostly thermokarst ponds and lakes located within peat sphagnum bogs; the bottom sediments of the lakes are dominated by peat detritus. Active thermokarst occurs due to the thawing of syngenetic and epigenetic segregation ice, ice wedges and ice layers in the deep $(>2 \mathrm{~m})$ horizons and the thawing of the active ice layer $(<2 \mathrm{~m})$. Because of the thermokarst activity, various negative relief forms develop (depression, subsidence and ponds) that are usually separated by flat mound peat bogs up to $2 \mathrm{~m}$ high (Kozlov, 2005). The largest thermokarst lakes of the region located within the peat bogs are up to several $\mathrm{km}$ in diameter and $0.5-1.5 \mathrm{~m}$ deep (Savchenko, 1992; Kozlov, 2005). All of the sampled thermokarst lakes in western Siberia were separated into five stages of evolution depending on their diameters (open water area) as fol-

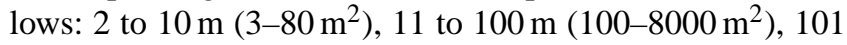
to $500 \mathrm{~m}\left(8000-200000 \mathrm{~m}^{2}\right),>500 \mathrm{~m}\left(>200000 \mathrm{~m}^{2}\right)$ and drained lakes (khasyreys) to $5000 \mathrm{~m}\left(200-50000 \mathrm{~m}^{2}\right)$, which correspond to the first, second, third, fourth and fifth stages, respectively. These stages were separated based on the empirical relative chronosequence of lake formation and cyclic development.

The small permafrost subsidence, ponds, lakes and drainage basins investigated in this study represent the typical sequence of thermokarst thawing and lake formation in the northern portion of Western Siberia, as described previously (Kirpotin et al., 2003, 2007, 2008, 2009a, b, 2011; Pokrovsky et al., 2011, 2013, 2014, Audry et al., 2011; Shirokova et al., 2009, 2013). These studies reveal that because the permafrost degradation and lake formation occurs on a highly homogeneous organomineral substrate in an essentially forest-free zone, the lakes are isomorphic, and their diameters (or surface area) may be the best surrogate for the degree of ecosystem development, specifically water body 
maturation. The sequence of events occurs as follows. The appearance of the crack in the lichen cover of the frozen mound surface decreases the albedo of the surface and enhances the peat degradation; consequently a shallow depression less than a few metres in diameter forms. The palsa depression is filled by the water from the thawed soil ice and partially by the rainwater. The size of the depression increases forming a shallow round pond $(<10 \mathrm{~m}$ diameter) which grows further into a small $(<100 \mathrm{~m}$ diameter) shallow $(<1 \mathrm{~m}$ depth) lake, which is characterised by the intensive peat abrasion at the border. When increasing the lake diameter further $(>100 \mathrm{~m})$, the lake border is stabilised, and the water becomes less acidic and less organic. The final stage involving large, mature aquatic ecosystems consists of the lake draining into another larger water system or the hydrological network, subsequently forming a dry lake bottom with a small water body remaining in the centre of the drained lake. All of the studied bodies of water ranged from $10 \mathrm{~m}$ to several $\mathrm{km}$ in diameter and had similar depth $(1.0 \pm 0.5 \mathrm{~m})$ under normal precipitation/evaporation conditions. The age of the lakes and the temporal scale of their evolution are currently unknown but should be similar to other thermokarst lakes worldwide - i.e. age of several decades to hundreds years, Grosse et al. (2013), with an axial increase in the expanding lakes of approximately $1 \mathrm{~m} \mathrm{yr}^{-1}$ (Burn and Smith, 1990). The connectivity between lakes and rivers is an important factor for the dynamics of the lake area and the temporal evolution in the permafrost zone (see Chen et al., 2013). All of the lakes sampled in the late summer in this study were closed-basin lakes that exhibited the lowest seasonal variability, similar to other studies in western Siberia (Karlsson et al., 2012) and Alaska (Chen et al., 2013). Finally, most of the studied thermokarst lakes have no continuous talik under their lake bottoms, unlike the lakes in the Alaskan boreal forest (i.e. Roach et al., 2011) or the large Siberian rivers. In contrast to the relatively deep $(>2 \mathrm{~m})$ thermokarst lakes in the sporadic/discontinuous permafrost zone of Alaska with taliks located underneath (e.g. Burn and Smith, 1990; Grosse et al., 2013), the shallow $(<1-1.5 \mathrm{~m})$ western Siberian thermokarst water bodies occurring within a zone with permafrost measuring at least $50 \mathrm{~m}$ in thickness that remained fully frozen during the ice period exhibited only seasonal taliks within the upper soil layers. The exceptions are the lakes on the Gyda Peninsula, which can be affected by the sea and thus have a partial connection with the underground water reservoir.

Due to the very flat orographic context of the palsa peat bogs, the studied water bodies do not have any inlets or outlets. The snow thaw water and the rainwater feeding these lakes via surface inflow from June to September simply follow the relief features. Because the lakes typically occupy between 40 and $60 \%$ of the territory in the studied sites, the watershed area of the lakes is tentatively equal to the water surface area. The lake diameter and surface area were determined on-site using a GPS navigator and verified from both topographical and Google Earth ${ }^{\circledR}$ maps. The sampling was performed within three major study sites, as shown in Fig. 1: (1) the coastal zone, around the village of Gyda in August 2011, (2) east of the Novyi Urengoy region in August 2011, and (3) the continental zone, including the district of Pangody (Yamalo-Nenetsk region), which is west of the Novyi Urengoy region in August 2010. Sites 2 and 3 lay north of the discontinuous permafrost zone, while coastal site 1 is located within the continuous permafrost zone. The data were compared to other information available regarding the chemical composition of the thermokarst ponds and lakes of western Siberia presented elsewhere (Shirokova et al., 2013; Pokrovsky et al., 2013). Thanks to this comparison, we could encompass a significant range of the climate, vegetation, and permafrost thickness and coverage from the Arctic tundra to the northern taiga developed on essentially the same mineral and peat substrate. A detailed and comparative description of the study sites is presented in Supplement Table S1.

We sampled 43 thermokarst lakes in the continental zone and 15 lakes in the coastal Arctic zone using an allterrain eight-wheeled vehicle (ARGO $8 \times 8700 \mathrm{HD}$ ). To characterise the variability of the thermokarst lakes along a $\sim 900 \mathrm{~km}$ latitude profile, the data on the lake water hydrochemistry in the southern part of the cryozone were also used. This previous study (Shirokova et al., 2013) is based on the samples collected during exactly the same period as site 2, which was in August 2010 south of the discontinuous permafrost zone. The sampled years are quite representative for the long-term precipitation and temperature regime, as well as the mean water budget (see discussion in Pokrovsky et al., 2013). Due to the hydrocarbon extraction in western Siberia, the surface and groundwater may be contaminated with oilfield brine (e.g. Collins, 1975; Alexeev et al., 2004). However, all of the studied lakes and ponds lay outside the oil extraction fields within the largest natural gas provinces, which therefore exert little impact on the surface ecosystems. Water samples were collected from the surface $(0.3$ to $0.5 \mathrm{~m})$ of the lakes in pre-cleaned polypropylene $250 \mathrm{~mL}$ containers and filtered on-site or within $4 \mathrm{~h}$ after sampling through disposable MILLEX filter units $(0.45 \mu \mathrm{m}$ pore size, $33 \mathrm{~mm}$ diameter) using sterile plastic syringes and vinyl gloves. The first $20-50 \mathrm{~mL}$ of the filtrate was discarded to condition the filters. The filtered sample was divided into two parts: one is acidified with bidistilled nitric acid to analyse the cations and trace elements, while the other part is kept without acidification for the DOC and anion analyses. Blanks were routinely generated by filtering Milli-Q water and analysing the final element concentrations; these blanks contained $<5 \%$ of the typical DOC and major cation and anion contents, $<10 \%$ of the divalent metal contents $(\mathrm{Zn}, \mathrm{Cu}, \mathrm{Fe}, \mathrm{Cd}, \mathrm{Pb})$ and $<2 \%$ for the other trace elements (TEs).

The DOC, $\mathrm{Cl}^{-}, \mathrm{SO}_{4}^{2-}$, Alk, cation and TE contents were measured using methods that are routinely practised in our laboratory during the analysis of boreal, organic-rich and low-mineralised water samples (see Vasyukova et al., 2010; 
Pokrovsky et al., 2010, 2011, 2012). The TEs were measured using inductively coupled plasma mass spectrometry (ICPMS, Agilent $7500 \mathrm{ce}$ ) with indium and rhenium as internal standards and a precision above $\pm 5 \%$. The international geostandards SLRS-4 and SLRS-5 (Riverine Water References Material for Trace Metals certified by the National Research Council of Canada) were used to assess the validity and reproducibility of each analysis. Good agreement (i.e. within $10 \%$ ) was obtained between our replicated measurements of SLRS and the certified values for all elements discussed in this study. In addition to these analyses, all of the lake water samples were measured using high-resolution ICP MS (Element XR) with a factor of 100-1000 as the lower detection limit for most of the elements and a relative uncertainty between 5 and $10 \%$. By significantly decreasing the detection limit, many new rare elements, which were previously unavailable during ICP MS analyses of the thermokarst lake waters, such as $\mathrm{Ge}, \mathrm{Ga}, \mathrm{Nb}, \mathrm{Ag}, \mathrm{Sn}, \mathrm{Te}, \mathrm{Tl}$, $\mathrm{Bi}, \mathrm{Hf}$, could be assessed for the first time while avoiding numerous interfering factors. The average agreement between the two ICP MS instruments for the majority of the TEs was within $10-15 \%$. The non-acidified sample was used for the following: (1) Si determination with ammonium molybdate on an AutoAnalyser 3 Bran + Luebbe with a $\pm 2 \%$ uncertainty and a $10 \mu \mathrm{g} \mathrm{L}^{-1}$ detection limit; (2) DOC analyses with total combustion at $800^{\circ} \mathrm{C}$ using a Pt catalyser (TOCVCSN, SHIMADZU) with $5 \%$ uncertainty and a detection limit of $0.1 \mathrm{mg} \mathrm{L}^{-1}$; UV absorbence at $280 \mathrm{~nm}$ (spectrophotometer Varicen, Cary 50 Scan. UV-Visible); chloride and sulfate analyses via liquid chromatography (DIONEX ICS2000) with an uncertainty of $2 \%$ and a detection limit of $0.02 \mathrm{mg} \mathrm{L}^{-1}$.

The elemental contents were analysed using best fit functions based on the least squares method, Pearson correlation and one-way ANOVA with STATISTICA version 8 software (StatSoft Inc., Tulsa, OK). Regressions and power functions were used to examine the relationships between the elemental concentrations and the lake surface areas. The correlation coefficients were calculated to elucidate the relationships between the organic carbon/Fe and TE concentrations in the lakes. The ANOVA was carried out using Dunn's method because each zone utilised a different number of samples (SigmaPlot version 11.0/Systat Software, Inc). A non-parametric Kruskal-Wallis $H$ test that determines whether three or more independent samples belong to the same population based on the medians was used to assess the difference in major and trace element concentration between different stages of lake development (lake size). In this regard, this method is analogous to the parametric oneway analysis of variance (ANOVA); in our case it reveals the difference between the different stages of lake development based on the concentration of each given element.

\section{Results and discussion}

\subsection{Specific conductivity and $\mathrm{pH}$}

All of the studied thermokarst sub-Arctic lakes from the continental zone should be fed by precipitation, as indicated by the low concentrations of the major anions (Supplement Table $\mathrm{S} 2$ ). The chloride and sulfate concentrations range from 0.014 to 1.12 and from 0.04 to $1.1 \mathrm{mg} \mathrm{L}^{-1}$, respectively, matching the range of the typical values for atmospheric precipitates in this region (Granat, 1972; Savichev, 2005; Moskovchenko and Babushkin, 2012).

The conductivity of the thermokarst lake waters does not exhibit any significant variations between the continental lakes with different surface areas, although the maximal values of conductivity ( $\sim 20$ to $30 \mu \mathrm{S} \mathrm{cm}^{-1}$ ) are recorded for the smallest water bodies corresponding to the 1st and 2nd stages (Fig. 2). In this and the subsequent figures, the sample populations were grouped by the stage of lake development for the southern part of the study region but not the north because the sequence of lake development, when translated into the lake size (surface area), is valid for continental sites in the south but might not be warranted for the coastal site of the north.

In the Arctic coastal zone, the conductivity is significantly higher $\left(73 \mu \mathrm{S} \mathrm{cm}^{-1}\right.$ on average, ranging from 40 to $250 \mu \mathrm{S} \mathrm{cm}^{-1}$ ), which corresponds to the higher major ion concentrations (Fig. 2). The surface waters of southern Gyda Bay are enriched in $\mathrm{Na}^{+}$and $\mathrm{Cl}^{-}$(Tomberg et al., 2011). The lakes sampled in the coastal Arctic zone contain from 0.6 to $6.9 \mathrm{mg} \mathrm{L}^{-1}$ chloride and 0.02 to $1.6 \mathrm{mg} \mathrm{L}^{-1}$ sulfate. The large variability in these ionic concentrations likely reflects the different degrees of influence for the marine aerosol. After disregarding a small depression, which presumably has marine aerosol influences, the Gyda coastal lakes exhibit an increase in conductivity when increasing in size. This observation, which opposes the data for the discontinuous and sporadic permafrost zone, may be linked to the effect of the marine aerosol deposits and the sea salt leached from the surrounding mineral substrate due to the proximity to the sea. Currently, the degree to which the precipitation could influence the hydrology of the coastal lakes remains unknown. The quaternary marine deposits (see Supplement Table S1) are absent in the southern continental part of the territory. The low Si concentrations in large lakes also suggest that the underground water contribution is relatively minor because the latter would bear a signature water-host rock interaction with elevated [Si]. Figure 2 shows that the studied thermokarst lakes exhibit the lowest specific conductivity compared to the other permafrost thaw water bodies reported in the literature, such as the Lena Delta (Abnizova et al., 2012). This low specific conductivity stems from the organic, but not the mineral, nature of the surrounding substrate.

The $\mathrm{pH}$ of the thermokarst lakes from the continental site ranged from 3.9 to 5.4; generally, the smallest water bodies 


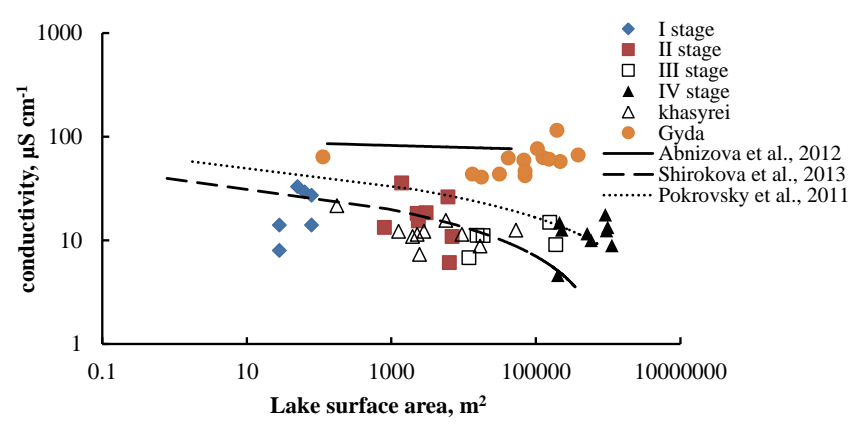

Figure 2. Lake water conductivity as a function of lake surface area in continental sub-Arctic zone of the Pangody and Novyi Urengoy sites (from the first to the fourth stage of formation and khasyrey shown by diamonds, rectangles and triangles) and the Gyda site (solid circles). See Supplement Table S2 for the correspondence between the lake stage of evolution and the lake surface area. Results of Abnizova et al. (2012), Shirokova et al. (2013) and Pokrovsky et al. (2011) correspond to thermokarst lakes and ponds sampled in Samoilov Island (the Lena Delta), discontinuous/sporadic permafrost of the Noyabrsk/Khanymey region, and the Novyi Urengoy region, respectively. They represent a powerful regression of concentration as a function of lake surface area.

in the first stage were more acidic compared to the other stages of lake development. This higher acidity stems from the leached acidic peat, which affects the lake water chemistry; this effect is more pronounced at the beginning of the thaw and at high solid substrate/surface fluid ratios. The lake circumference increases linearly with the thermokarst expansion, while the lake area increases exponentially. Consequently, a lower amount of thawed peat materials relative to lake water volume contribute as the thermokarst lake grows in size. This observation is illustrated by a distinct trend of increasing $\mathrm{pH}$ when increasing the lake size in this region (Supplement Table S2). Therefore, most of the studied western Siberian thermokarst ponds and lakes are significantly more acidic than the other reported thermokarst shallow bodies in North America (i.e. 6.8 to 8.5, Rautio et al., 2011). In contrast, the coastal lakes of the Arctic zone, which are located within the clays and sands of the contemporary marine sediments within a much thinner peat horizon (see Supplement Table S1), are influenced by spring flooding and the proximity to the sea; therefore, they exhibit a significantly higher $\mathrm{pH}$ (6.2 to 6.6).

\subsection{Dissolved organic carbon}

A high concentration of dissolved organic matter (DOM) is typical for the studied thermokarst lakes. In the Russian boreal zone, the organic matter leached from the peat and bog soils provides a significant concentration of DOM and a low concentration of inorganic ions (Alekin, 1953). Consequently, the DOM often constitutes more than $50 \%$ of the total solutes, particularly in the northern portion of western Siberia, including the Tazovsky district (Savchenko, 1992).
The peat thickness, which varies from 0.2 to $0.5 \mathrm{~m}$ in the north and from 2 to $4 \mathrm{~m}$ in the south (see Supplement Table S1), most likely controls the DOC enrichment of the surface water in various permafrost zones. Overall, the DOC concentration of the studied lakes shown in Fig. 3 agrees with the trends reported for the area north of the discontinuous permafrost zone of the Novyi Urengoy region (Pokrovsky et al., 2011), the discontinuous/sporadic permafrost region (Shirokova et al., 2013) and the upland lakes of the Mackenzie Delta region (Kokelj et al., 2005). Concurrently, the western Siberia thermokarst lakes are richer in DOC compared to the lakes of the Canadian sub-Arctic (Laurion et al., 2010; Bouchard et al., 2012) and the Lena Delta (Abnizova et al., 2012).

The analyses of the thermokarst lakes from the continental zone revealed a higher concentration of DOC at the first and second stages $\left(18.1 \pm 15.4\right.$ and $15.3 \pm 8.1 \mathrm{mg} \mathrm{L}^{-1}$, respectively) compared to the mature stages $(11.0 \pm 4.3$ and $11.1 \pm 3.4 \mathrm{mg} \mathrm{L}^{-1}$, for third and fourth stages, respectively) (Fig. 3). This progressive decrease in the DOC concentration during ecosystem development, which corresponds to thermokarst lake growth and maturation, may stem from the combination of two parallel processes: (1) the enrichment of the water column when leaching peat at the lake border and the thawing of surface soil ice; (2) the heterotrophic mineralisation of DOM by aerobic bacterioplankton in the water column. Both processes operate in the thermokarst lakes within discontinuous (Pokrovsky et al., 2011) and sporadic/discontinuous (Shirokova et al., 2013) permafrost zones.

All the lakes, regardless of their size and geographic zone, exhibited a strong correlation between the DOC $(<0.45 \mu \mathrm{m})$ and the UV absorption at $280 \mathrm{~nm}\left(R^{2}=0.90\right.$, not shown). This correlation corresponds to the high level of aromaticity (Summers et al., 1987; Weishaar et al., 2003; Helms et al., 2008) and suggests an allochthonous origin (i.e. peat soil leaching) for the dissolved OM from the beginning of permafrost thaw until the ecosystem matures, which is well pronounced across the permafrost gradient studied in this work. In the discontinuous and sporadic permafrost zone, after a progressive increase in the ratio of the water volume to the board perimeter, the input of allochthonous DOM to the lake decreases based on the mass balance calculations, while the intensity of heterotrophic respiration of DOM into $\mathrm{CO}_{2}$ remains constant (Shirokova et al., 2013). This behaviour decreases the DOC concentration during the maturation of the lake ecosystem. Presumably, similar mechanisms for DOC decreases that occur with the maturation of the lake operate in other continental permafrost sites considered in the present study, as shown in Fig. 3.

An additional reason for the decreased DOC concentration in large, mature lakes may be the photo-oxidation of high-molecular-weight organic substances in the water column, which is fairly well known in other boreal and subArctic aquatic systems (Laurion et al., 2000; Kohler et al., 


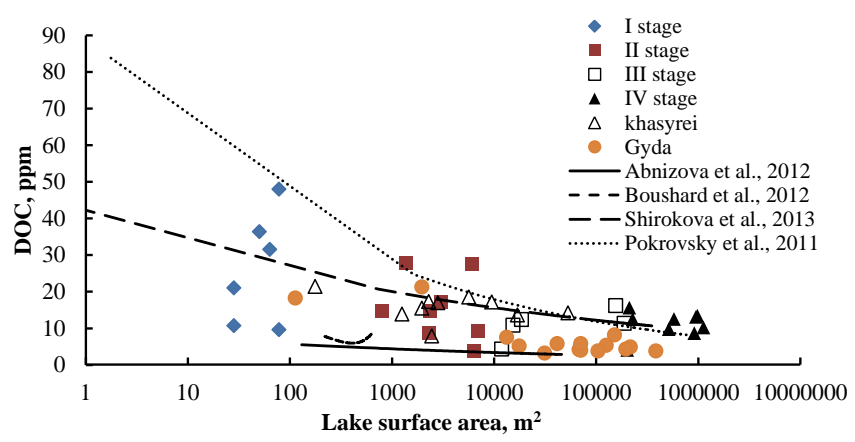

Figure 3. DOC $(<0.45 \mu \mathrm{m})$ concentration in studied water bodies as a function of their surface area. The symbol description is the same as in Fig. 2. Results of Bouchard et al. (2012) are from subArctic Quebec thermokarst lakes and ponds and those of Abnizova et al. (2012), Shirkova et al. (2013), and Pokrovsky et al. (2011) are described in Fig. 2.

2002; Cory et al., 2007; Thorn et al., 2010; Pokrovsky et al., 2011; Shirokova et al., 2013). Overall, the degree of DOC decrease should be controlled by the residence time of the water and the dissolved components in the lake, similar to streams in the permafrost regions (see Jantze et al., 2013). During lake maturation in western Siberia, no changes in the lake drainage basin are detected relative to the soil chemical and mineralogical composition (essentially frozen peat) or vegetation (dwarf shrubs with moss and lichen cover, see Pokrovsky et al., 2014). Therefore, the relative impact of the allochthonous processes at the watershed on the lake chemical composition should decrease when increasing the lake size due to the decreased ratio of lake drainage area / lake volume.

After a significant lake drainage and khasyrey formation during the last stage, the DOC content increases to $15.6 \pm 3.6 \mathrm{mg} \mathrm{L}^{-1}$. This increase may be linked to the presence of aquatic plants, phytoplankton and periphyton, which contribute to the production of autochthonous exometabolites and therefore increase the DOC level and lability in the lake water. Similar phenomena were observed in the Mackenzie Delta lakes (Tank et al., 2009, 2011).

The DOC in the water column of the Arctic lakes from the coastal zone of the Gyda region ranged from 3.2 to $21.3 \mathrm{mg} \mathrm{L}^{-1}$; the highest concentrations were encountered in the smallest $(<100 \mathrm{~m}$ diameter $)$ water bodies. The average DOC concentration was $7 \mathrm{mg} \mathrm{L}^{-1}$, which is two times lower than the continental lakes. The difference in DOC between lakes varying in size from the continuous and discontinuous permafrost zone is comparable to the northward decrease in DOC across the tree-line tundra transition reported by Vincent and Pienitz (1996).

\subsection{Major and trace element concentrations in the thermokarst lakes}

A distinguishing factor for the studied water bodies is that $\mathrm{Fe}$ and $\mathrm{Al}$ are some of the major dissolved components in the water column. In the discontinuous and sporadic permafrost zone of western Siberia, the speciation of most trace elements is controlled by their association with Fe, Al-rich organomineral colloids and allochthonous organic matter originating from peat leached at the lake border and, at the beginning of the thermokarst development, the lake bottom (Pokrovsky et al., 2011, 2014). Consequently, a correlation between the concentration of TE and that of their main carriers in the lake waters (organic matter, $\mathrm{Fe}$, and $\mathrm{Al}$ colloids) might be expected. Examples of the correlations between the major lake water parameters (Al, Fe, DOC and specific conductivity) are shown in Fig. 4. The Fe and $\mathrm{Al}$ have a significant correlation with the DOC $\left(R^{2}=0.84, R=0.91(p<0.0001)\right.$ and $0.60(p<0.0001)$, respectively) over the full size of lakes and ponds both in the continuous coastal and discontinuous continental sites.

The highest concentrations of $\mathrm{Fe}$ and $\mathrm{Si}$ are observed at the beginning of the lake formation, while the lowest concentrations of these components are encountered in large mature lakes, as illustrated in the plots of the major and TE concentrations as a function of the lake diameter (Fig. 5a-b). The Arctic coastal lakes of continuous permafrost zone contain significantly higher alkali $(\mathrm{Na}, \mathrm{K})$ and alkaline-earth $(\mathrm{Ca}$, $\mathrm{Sr}$ ) concentrations compared to the continental (southern) thermokarst lakes (Supplement Tables S2 and S3) due to the influence of the sea salts, which may be marine aerosols or saline waters fed underground. Notably, the hosted rocks of the Arctic lakes represented by the Neocene marine clay deposits also contain a significant amount of easily exchangeable alkali and alkaline earth metals, similar to the marine sediments influencing the rivers of the White Sea coast in the European sub-Arctic (Vasyukova et al., 2010).

The average measured elemental concentrations in the water column of the studied thermokarst water bodies from the southern (continental) zone are listed in Supplement Table S3. The surface waters in the northern part of western Siberia present a low concentration of total dissolved ions and labile major and trace elements, such as $\mathrm{Na}, \mathrm{Mg}, \mathrm{Si}, \mathrm{K}$, $\mathrm{Ca}, \mathrm{Li}, \mathrm{B}, \mathrm{Mn}, \mathrm{Rb}, \mathrm{Sr}, \mathrm{Mo}, \mathrm{Ba}$ and $\mathrm{U}$, which primarily originated from deep and shallow groundwater discharge during the mineral weathering reactions. Essentially, the peatlike (organic) nature of the hosting solid substrate for the thermokarst lakes elevates the DOC contents and acidifies the waters compared to other lakes located within the mineral substrates in the continental part of eastern Siberia (loesses) and the Alaskan Arctic, particularly the Mackenzie Delta (i.e. Kokelj et al., 2009). The TE concentrations in the western Siberian thermokarst lakes are much higher compared to the metal concentrations in the glacial lakes of the Northwestern Territories in Canada (Pienitz et al., 1997a, b; 

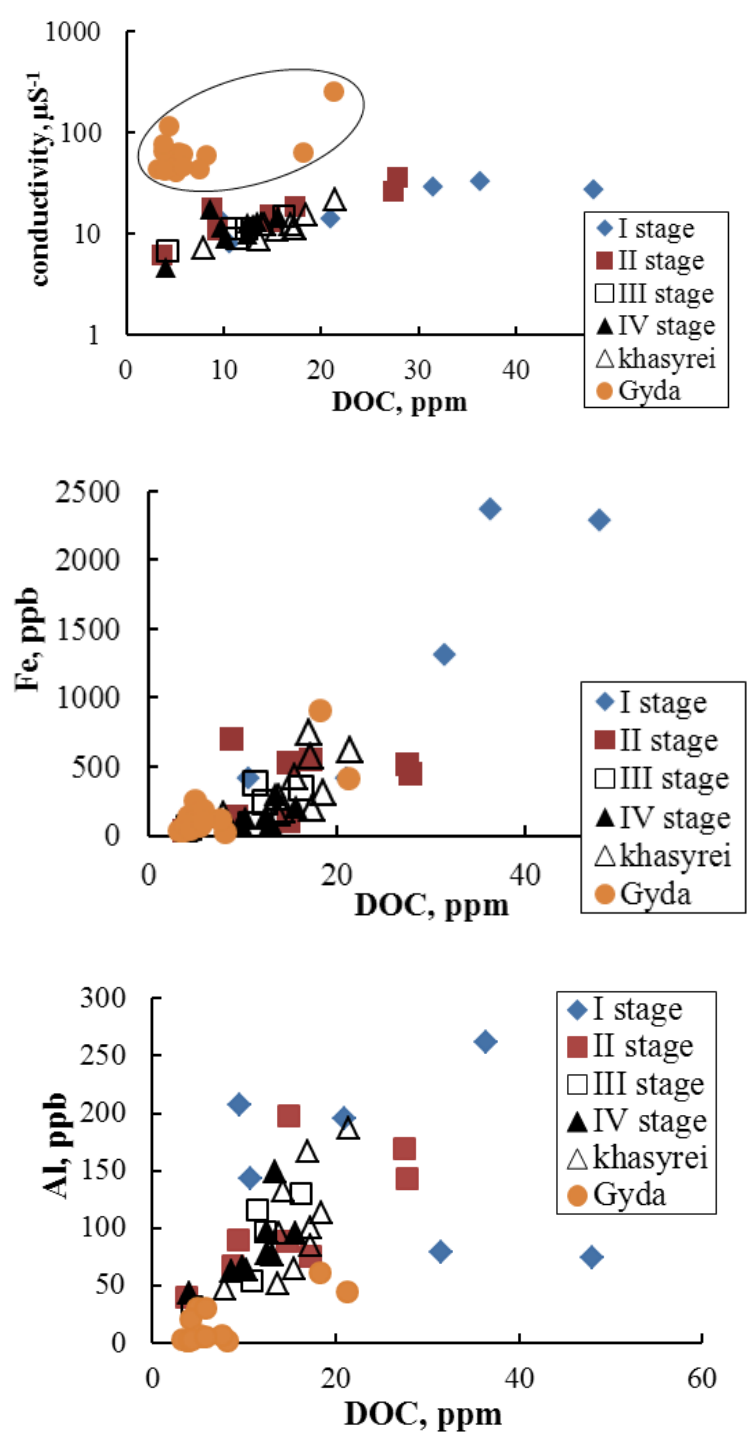

Figure 4. Dependency of conductivity (A), Fe (B) and Al (C) concentration on DOC concentration in thermokarst lakes of different stage of development. The symbol description is the same as in Fig. 2. The circle in (A) represents the data of Arctic coastal lakes (Gyda site) exhibiting an order of magnitude higher conductivity at otherwise similar DOC.

Rühland and Smol, 1998; Lim et al., 2005; Côté et al., 2010), the Canadian High Arctic (Lim et al., 2001; Michelutti et al., 2002a, b; Antoniades et al., 2003) and thermokarst lakes of the Arctic Alaska (Kling et al., 1992); and central Yakutia (Kumke et al., 2007; Wetterich et al., 2008) and northern Eurasia (Duff et al., 1999; Solovieva et al., 2005).

Based on the non-parametric $H$ test by Kruskal-Wallis, statistically significant differences are detected between differently sized and developed lakes for Fe $(H=12.6, p=$ 0.0132), $\mathrm{Na}(H=19.8, p=0.0006), \mathrm{Mg}(H=10.9, p=$ $0.0283), \mathrm{K}(H=24.9, p=0.0001), \mathrm{Zn}(H=10.2, p=$ $0.0374)$, and $\operatorname{Cr}(H=10.3, p=0.0360)$. Specifically, a sys-

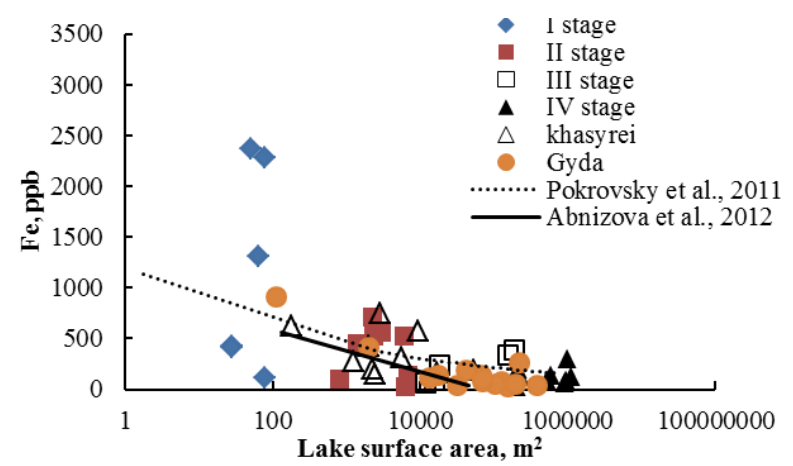

A

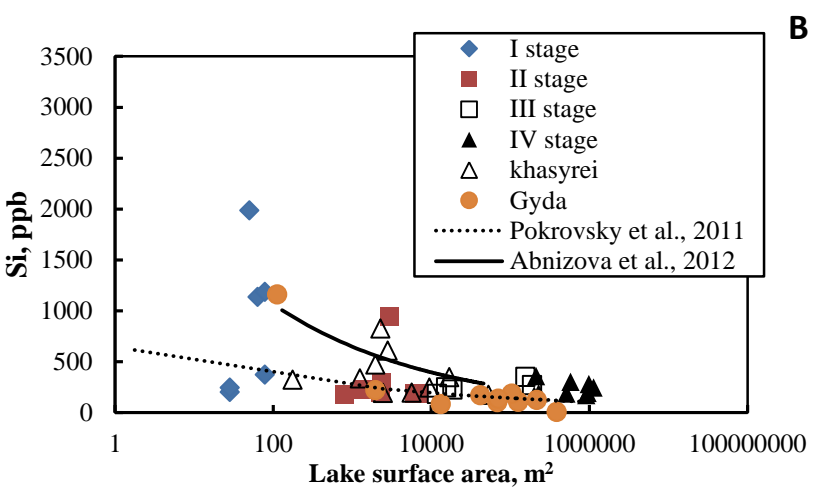

Figure 5. Fe (A) and $\mathrm{Si}(\mathbf{B})$ concentration in the water column as a function of lake surface area. The symbol description is the same as in Fig. 2. Data of Pokrovsky et al. (2011) and Abnizova et al. (2012) are from the discontinuous permafrost zone of western Siberia and the Lena Delta observatory, respectively. Due to the lack or the high dispersity of published lake water concentration data points, results of the other studies could not be adequately represented.

tematic evolution of the thermokarst lake chemical composition can be observed from the $\mathrm{Fe}-\mathrm{Si}$ waters at the beginning of lake formation to the $\mathrm{Ca}-\mathrm{Na}-\mathrm{Mg}$ dominance in the mature, fourth-stage lakes. The terminal fifth stage is characterised by increased relative contributions of $\mathrm{Si}$, $\mathrm{K}$ and $\mathrm{Fe}$. The Arctic coastal lakes exhibit the following order of decrease in dissolved element concentrations: $\mathrm{Na}>\mathrm{Mg}>\mathrm{Ca}>\mathrm{K}>\mathrm{Si}>\mathrm{Fe}>\mathrm{Al}>\mathrm{Zn}>\mathrm{Sr}>\mathrm{Mn}$. Therefore, the studied lakes in the coastal continuous permafrost zone are similar to the mature thermokarst lakes of the fourth stage from the continental zone, with a somewhat smaller contribution from $\mathrm{Fe}$ and $\mathrm{Si}$ and an increased contribution from $\mathrm{Na}$ due to the proximity of the sea.

The data obtained on the thermokarst lake composition allowed us to distinguish four groups of chemical elements, reflecting the dynamic succession of lake development from the first to the last stage: (1) elements whose concentrations decreased from 20 to $90 \%$ during lake maturation include $\mathrm{Cr}, \mathrm{Cs}, \mathrm{Mo}, \mathrm{Ga}$; (2) elements whose concentrations increased by 35 to $55 \%$ include $\mathrm{Ca}, \mathrm{Li}, \mathrm{Mg}, \mathrm{Se}$; (3) the elements with 
the highest concentrations at the first and last stages, which was the lowest in mature thermokarst lakes $>100 \mathrm{~m}$ diameter, with the relative variations between different stages from 26 to $83 \%$ include $\mathrm{As}, \mathrm{Co}, \mathrm{Fe}, \mathrm{Al}, \mathrm{Si}, \mathrm{Cd}$; (4) elements whose concentration was the lowest at the beginning and the end of ecosystem development and was the highest in mature lakes larger than $100 \mathrm{~m}$ in diameter include $\mathrm{V}, \mathrm{U}, \mathrm{Rb}, \mathrm{B}, \mathrm{K}$ and major anions $\left(\mathrm{Cl}^{-}, \mathrm{SO}_{4}^{2-}\right)$ with relative variations between 32 and $83 \%$. The decrease in the first and third element group concentrations over the course of the lake ecosystem development may be linked to the colloidal status of these elements, as demonstrated in other thermokarst aquatic environments (Pokrovsky et al., 2011; Shirokova et al., 2013). The decreased DOC and Fe concentrations over the course of the development of lake ecosystems decreases the concentration of allochthonous organomineral colloids, which bind these trace elements.

\subsection{Trace element concentration dependence on the lake surface area}

The correlation coefficient between the element concentration and the lake diameter is element specific and generally negative; specifically, the concentration decreases when increasing the lake diameter, as observed for DOC, Al, Fe, Mn, Co, Zr, rare earth elements (REEs) and Th (Supplement Table S4). Examples of the typical relationships between the element concentration and the water body surface area are illustrated in Fig. 6 for several groups of trace elements: divalent metals ( $\mathrm{Zn}, \mathrm{Cu}, \mathrm{Ni}$ and $\mathrm{Pb}$, panels $\mathrm{A}-\mathrm{D})$, oxyanions and neutral molecules (Mo and As, panels $\mathrm{E}$ and F), trivalent and tetravalent hydrolysates ( $\mathrm{Al}$ and $\mathrm{Zr}$, panels $\mathrm{G}$ and $\mathrm{H}$ ) and soluble, marine aerosols/saline deposits - originated elements ( $\mathrm{Rb}$ and $\mathrm{U}$, panels I and $\mathrm{J}$ ). For the thermokarst lakes of the continental permafrost zone, we observe the following: (1) clear tendencies for the TE concentration to change with the size of the water body and (2) significant differences in the element concentrations at different stages of lake development with similarly sized water bodies (i.e. second stage and khasyreys).

The results from the Arctic coastal lakes in the continuous permafrost zone follow the general trends obtained for the continental region; however, some peculiarities remain. Similar to the significantly less acidic $\mathrm{pH}$ of the latter, the concentration of typical insoluble elements, such as $\mathrm{Al}$ or $\mathrm{Zr}$, in $>100 \mathrm{~m}$ diameter lakes is significantly smaller in the Gyda region compared to the continental zone (Fig. 6g and h). Tetravalent hydrolysates (Ti, Zr, Hf, Th) do not exhibit any significant difference in their concentrations at different stages of lake development, beginning with the second/third stage, until the drained lake stage (khasyreys). This observation may suggest a lack of input of silicate material from underground sources or atmospheric dust deposits.

The decreased element concentrations with the water body area increase are typical for the elements supplied to the lake water from the leached peat and plant litter; these components are then actively removed from the water column during chemical and microbiological processes without significant atmospheric or underground input. For example, this observation may be true for all divalent transition metals. Elements influenced by atmospheric or underground input from sea salts are Rb, Sr, B and U (Fig. 6i and j). Based on both the non-parametric Kruskal-Wallis $H$ test and the parametric one-way analysis of variance (ANOVA), Rb and U demonstrate statistically significant concentration increases when the lake diameter increases to the fourth stage before the lake drains.

To reveal the specificity of the chemical composition of thermokarst lakes at the beginning of their formation, we calculated the ratio of average element concentrations in the smallest water bodies (permafrost subsidence and depressions $<80 \mathrm{~m}^{2}$ area) to the average value for the larger lakes, which is illustrated as a stack diagram in the Electronic Supporting Information (Fig. S1). At the beginning of the lake formation, a significant enrichment ( $\geq$ factor of 2 ) in $\mathrm{Fe}, \mathrm{Si}$, $\mathrm{Ga}, \mathrm{Pb}, \mathrm{Cd}$ and insoluble trivalent and tetravalent elements that are bound to DOC and Fe occurs in the lake water. After the development and increase in the size of the lakes, $\mathrm{Zn}, \mathrm{Ba}$, As, Ni, Cr, Ti, Mo, W, Y, Ce, and La decrease in concentration, while $\mathrm{K}, \mathrm{Rb}, \mathrm{Se}, \mathrm{Li}, \mathrm{Cu}$, and, to a lesser degree, $\mathrm{Mg}$ and $\mathrm{Sb}$ increase in concentration. The significant increase in $\mathrm{Si}$ and $\mathrm{K}$ (and its isomorphic $\mathrm{Rb}$ ) after lake maturation may be linked to the release of these elements from decaying plant litter and aquatic macrophytes present at the final stage of lake evolution. Minimal changes in the concentration were recorded for $\mathrm{Na}, \mathrm{V}, \mathrm{Sb}, \mathrm{U}, \mathrm{Ca}$ and $\mathrm{Mn}$. These elements are not strongly associated with organoferric colloids. Therefore, these elements are not correlated with the $\mathrm{DOC}, \mathrm{Fe}$ or $\mathrm{Al}$, which are the major colloidal components of the lake water; these elements are also significantly transformed during lake maturation. In addition, these elements do not have significant external sources (atmospheric aerosols, industrial activity) and, thus, act as highly conservative constituents of thermokarst lake water in western Siberia. A detailed analysis of correlations between the elements in the thermokarst water bodies is presented in Supplement Fig. S2.

\subsection{DOC and metal concentration in thermokarst lakes of western Siberia across a $900 \mathrm{~km}$ latitude and permafrost profile}

Given the large geographic coverage of the thermokarst lakes studied in this work and investigated previously $\left(\sim 10^{\circ}\right.$ latitude along a strongly pronounced gradient of permafrost thickness from the sporadic and discontinuous zone in the south of Noyabrsk district to continuous zone in the Gyda region), the effect of the degree of permafrost coverage on the lake water hydrochemistry can be assessed (Fig. 7). This representation may be partially biased because the coastal Gyda lakes are subjected to the influence of marine aerosols. For 

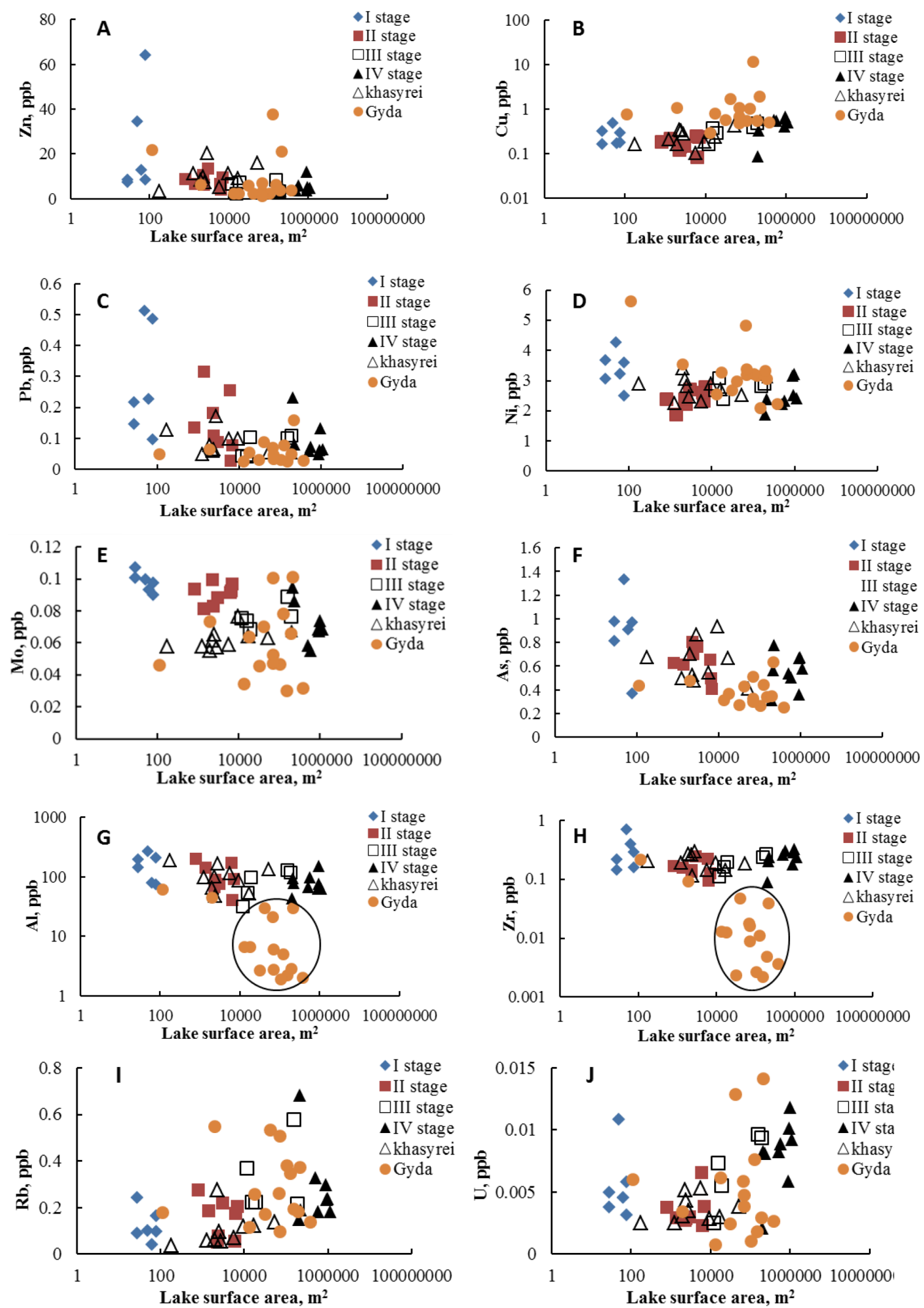

Figure 6. Trace elements concentration dependence on the lake surface area. The symbol description is the same as in Fig. 2. 
this analysis, we used the geometric mean values of the element concentrations in the lakes sampled during the summer from 2008-2012 for four size ranges of thermokarst water bodies; the dominant types were the small and medium lakes 100 to $500 \mathrm{~m}$ in diameter.

To assess the effect of the latitude and permafrost coverage on the thermokarst lake chemical composition, we selected the major components of the lake water (DOC, $\mathrm{pH}$, $\mathrm{Ca}, \mathrm{K})$, low-soluble trace metals ( $\mathrm{Al}, \mathrm{Fe}, \mathrm{Zr}$ ), several environmentally important heavy metals, such as $\mathrm{Mn}, \mathrm{Co}, \mathrm{Cu}$, $\mathrm{Ni}, \mathrm{Pb}$ and $\mathrm{Cr}$, and soluble elements bearing the signature of marine deposits or aerosols (Sr, Mo). To interpret the data shown in Fig. 7, we used Spearman's rank correlation coefficient $\left(r_{\mathrm{S}}\right)$ at $p<0.05$ because our data are not distributed according to the normal law. Four distinct patterns of element concentrations are revealed in the lake water versus the lake position on the latitude profile illustrated in Fig. 7a-n: (1) $\mathrm{DOC}, \mathrm{Pb}, \mathrm{V}, \mathrm{Ba}$ and $\mathrm{Sb}$ decrease in concentration from the south to the north with a factor of 2 to 4 ; (2) Si, Fe, Al, As, REE demonstrate a non-systematic evolution in concentration with relatively small variations in the latitude with a decrease below twofold from south to north; (3) Mn, Co, Cd, $\mathrm{Cs}, \mathrm{Zr}, \mathrm{Hf}$, Th exhibit a maximum concentration at the northern border of the discontinuous permafrost zone, up to five times compared to the adjacent sites, and a decrease of two to three times compared to the northern site; (4) the specific conductivity $\mathrm{Cl}, \mathrm{Ca}, \mathrm{Na}, \mathrm{Mg}, \mathrm{K}, \mathrm{Sr}, \mathrm{Cu}, \mathrm{Ni}$ and $\mathrm{Cr}$ increase in concentration from the south to the north by 3 to 10 times, depending on the size of the water body.

The latitudinal profile of the DOC concentration demonstrates a general decrease in [DOC], which is more than threefold from the most southern to most northern thermokarst lakes (Fig. 7a). This decrease is statistically significant $\left(r_{\mathrm{S}}=-0.39\right)$ and valid for the full range of lake sizes. Therefore, if the increased permafrost thaw in the north of western Siberia will provoke a shift from continuous to discontinuous/sporadic permafrost, the concentration of DOC in small surface water bodies may increase by as much as $300 \%$. Within the soil warming scenario, the primary mechanisms governing these changes are as follows: (i) elevated temperatures, (ii) increased duration of the active period and (iii) increased thickness of unfrozen peat layer deposits feeding the lakes via surface inflow.

The effect of the local atmospheric and long-range input can be accessed by comparing the dissolved element concentrations in otherwise similar thermokarst lakes located at different distances from the sea or from industrial pollution centres. When approaching the sea (northward), the concentration of $\mathrm{Ca}^{2+}$ and the major cations and anions, as well as the typical trace elements that are enriched in the seawater relative to the continental waters, such as $\mathrm{Sr}$ (Fig. $7 \mathrm{~m}$ ) and Mo (Fig. 7n), increase for the lakes in all size ranges. For the heavy metals, a pronounced increase in the $\mathrm{Cu}, \mathrm{Ni}$ and $\mathrm{Cr}$ concentrations (Fig. 7i, k and 1, respectively) is observed in the most northern region of the continuous per- mafrost zone (Gyda site) within approximately $300 \mathrm{~km}$ from the largest Arctic smelter $(\mathrm{Cu}-\mathrm{Ni}-\mathrm{Cr}$ processing factories in Norilsk). This increase is clearly observed for the large lakes, which can more easily integrate the atmospheric deposition. For the other heavy metals, the effect of the proximity to the sea or to the industrial centre is not pronounced. Notably, the concentration of $\mathrm{Pb}$ decreases to the north as the permafrost regime changes from discontinuous/sporadic to continuous (Fig. 7j). This decrease may reflect the decrease in the intensity of the $\mathrm{Pb}$ leached from peat, which accumulates this element (Shotyk et al., 2000).

\section{Concluding remarks}

To understand the chemical composition of thermokarst lake waters in the sub-Arctic, this work revealed general features of thermokarst depressions, ponds and lakes in the continental part of the discontinuous and coastal region of the continuous permafrost zone of the northern region of western Siberia. Within the continental permafrost zone of the thermokarst lakes, we observe a systematic evolution of the chemical composition of the water bodies while their ecosystems develop from small permafrost subsidence, depressions and ponds to large thermokarst lakes. This trend consists of decreasing DOC, Fe and many low-mobile TE concentrations during maturation and size increases, which are most likely linked to peat leaching at the lake border and heterotrophic DOM respiration in the water column. After the lake drains and the active macrophytes grows in the khasyreys(drained lakes), the DOC and some elements, such as $\mathrm{K}, \mathrm{Rb}, \mathrm{Cu}, \mathrm{Mg}, \mathrm{B}$ and $\mathrm{Sb}$, increase again due to the autochthonous biological processes.

Compared to the lakes in the continental site (N Urengoy and Pangody) of the permafrost zone located at the watershed divide, the coastal thermokarst lakes from the continuous permafrost exhibit 2 to 10 times lower concentrations of DOC and the most insoluble elements ( $\mathrm{Al}, \mathrm{Fe}$, trivalent and tetravalent hydrolysates) and 2 to 5 times higher concentrations of anions, alkali and alkaline-earth elements. Moreover, the lakes at Gyda do not exhibit any clear trends for the concentrations of most of the dissolved constituents (except DOC) relative to the lake size. The coastal lakes of the continuous permafrost zone do not follow the trend of [TE]; the lake size evolution was observed in this study for the discontinuous permafrost zone and established earlier in the sporadic permafrost zone. This difference is important when comparing the hydrochemical data with that of other subArctic zone sites because most of the information available on thermokarst lakes in other sub-Arctic regions belongs to the coastal regions.

The major and trace element concentrations exhibited a gradually decreasing trend as the logarithm of the lake surface area increased, reflecting the decreased input of the allochthonous sources (peat leaching at the lake border) during 
A
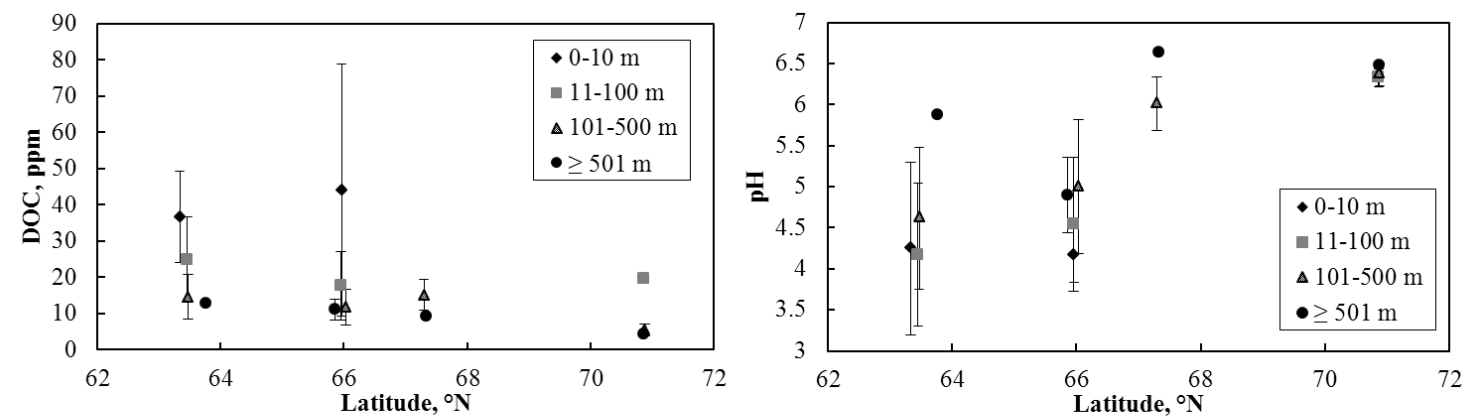

C
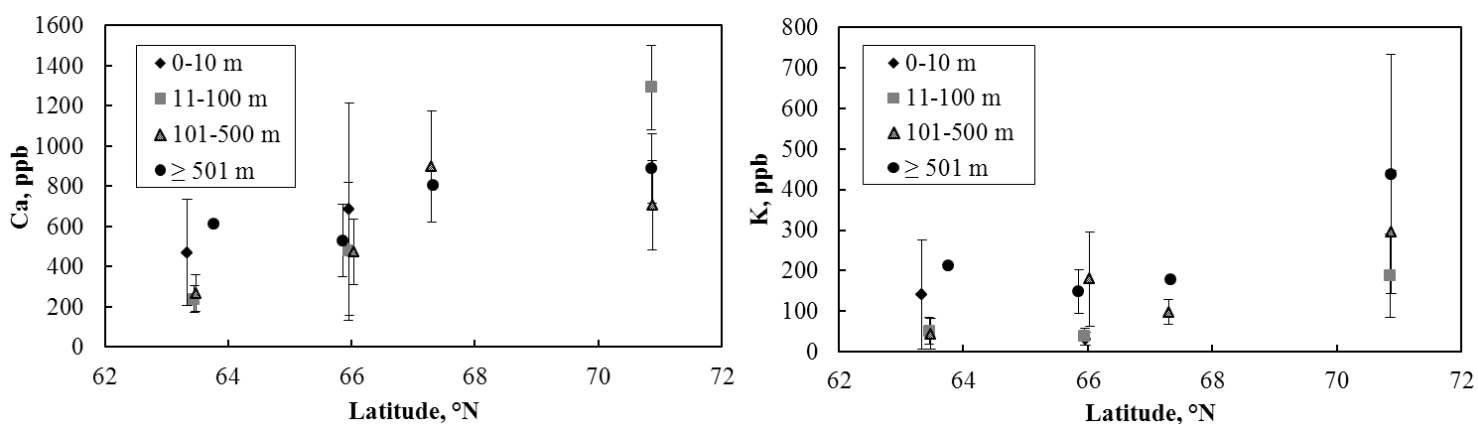

Figure 7. Lake water $\mathrm{pH}, \mathrm{DOC}, \mathrm{Ca}$ and $\mathrm{K}$ concentration in thermokarst lakes as a function of latitude in discontinuous/sporadic and continuous permafrost zone of western Siberia. The average values with standard deviation are calculated for each stage of lake development, corresponding to different lake diameter. In addition to the results of the present study, data of Shirokova et al., 2009; 2013 and Pokrovsky et al. (2011) were used.
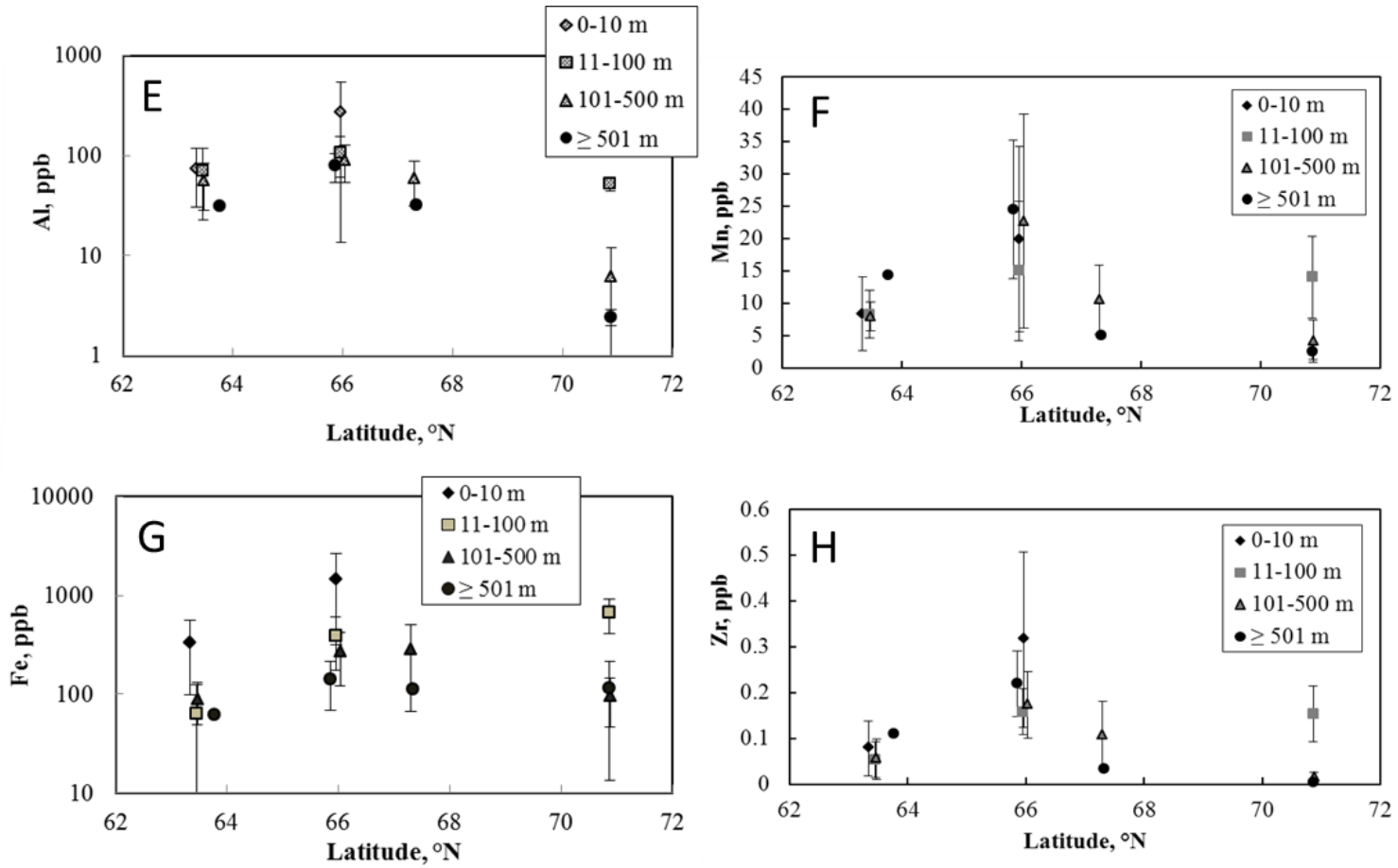

Figure 7. Lake water $\mathrm{Al}(\mathbf{E}), \mathrm{Mn}(\mathbf{F}), \mathrm{Fe}(\mathbf{G})$, and $\mathrm{Zr}(\mathbf{H})$ concentration in thermokarst lakes as a function of latitude. Note the logarithmic scale for $\mathrm{Fe}$ and $\mathrm{Al}$ concentration. 
I
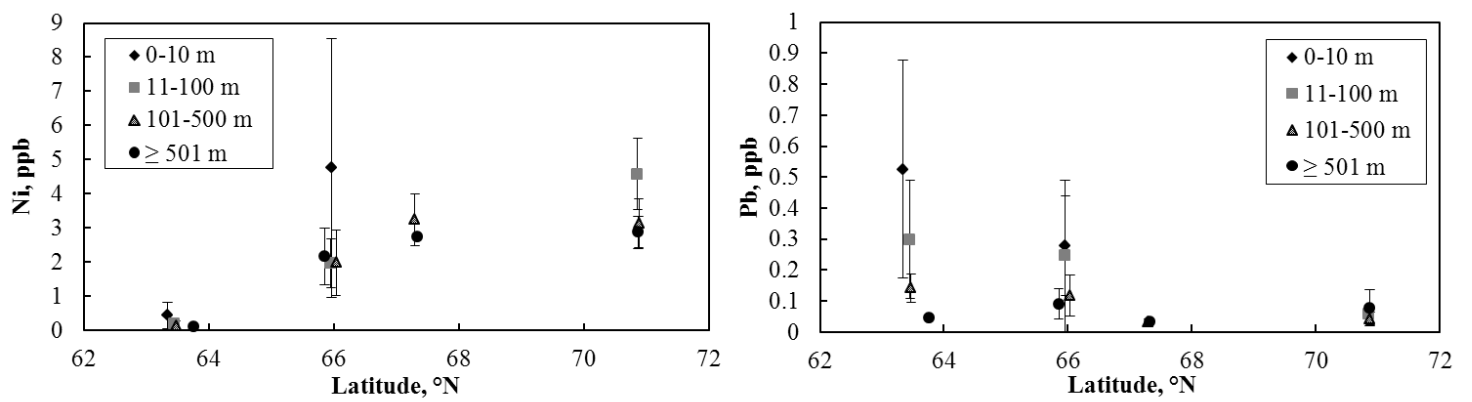

K
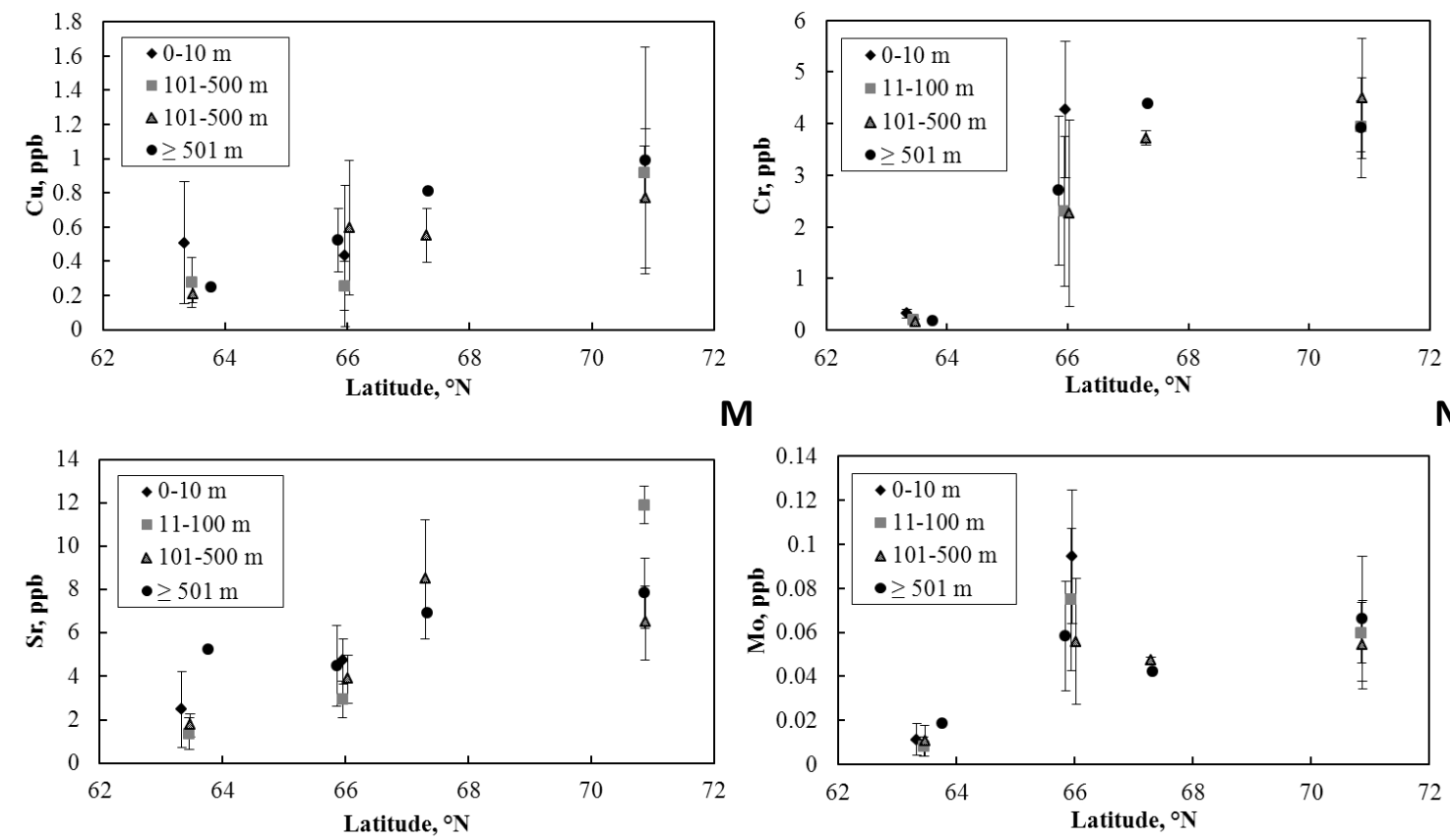

Figure 7. Lake water $\mathrm{Ni}, \mathrm{Pb}, \mathrm{Cu}, \mathrm{Cr}, \mathrm{Sr}$ and Mo concentration in thermokarst lakes as a function of latitude.

lake growth and ecosystem maturation. The exceptions are $\mathrm{Cu}, \mathrm{Ni}, \mathrm{Mo}, \mathrm{Rb}$ and $\mathrm{U}$, whose concentrations increase with the lake size due to ongoing bioaccumulation/biodegradation processes and underground feeding. The observed relationships are hypothesized to be valid for the continental part of the sporadic and discontinuous permafrost zone, and can presumably be extended farther north in the continuous permafrost zone far from the coast.

Concurrently, for each range of the thermokarst lake size, we observe a clear gradient for the $\mathrm{DOC}, \mathrm{pH}$, major and trace element concentrations from 63 to $71^{\circ} \mathrm{N}$ (sporadic to continuous permafrost zone), reflecting the decreased influence of deep the groundwater and surrounding peat thickness and the increased proximity to the sea and ore processing facilities.

The acceleration of the permafrost thaw in the northern portion of western Siberia (Kirpotin et al., 2009a, b; Bryksina et al., 2009; Dneprovskaya et al., 2009; Bryksina and Kirpotin, 2012) should increase the amount of small soil sub- sidence and permafrost depressions while decreasing the amount of large (mature) lakes. For example, a net increase in the amount of lakes was observed for the Nadym watershed (north of western Siberia and close to continental sites of this study), which is explained by the formation of small lakes, while the larger lakes fragment after partial drainage (Karlsson et al., 2014). Consequently, an increase in the concentration of dissolved, but a decrease in the low bio-available, soil organic matter, as well as most trace metals present as organic and organomineral colloids, can be expected. Based on the empirical relationships between the size (stage development) and concentrations of the trace elements, the average increase in concentration may range from 200 to $400 \%$. Further drainage of these water bodies to the river networks may significantly increase the contents of the $\mathrm{OC}$, metal nutrients and insoluble elements that are delivered from this inland wetland zone to the Arctic Ocean. 


\section{The Supplement related to this article is available online at doi:10.5194/tc-8-1177-2014-supplement.}

Acknowledgements. We are grateful to three anonymous reviewers for their insightful and constructive comments. This work was supported by BIO-GEO-CLIM grant of the Russian Ministry of Education and Research and Tomsk State University (no. 14.B25.31.0001), ANR "Arctic Metals", GDRI CAR-WETSIB, and grants RFBR 14-05-31457 mol_a, 14-05-31533 mol_a, program of Presidium UroRAN no. 12-Y-5-1034, "Arktika “ 12-5-4-007.

Edited by: S. Gruber

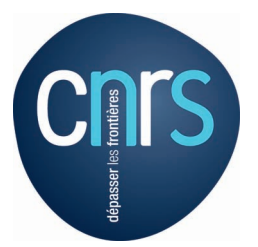

The publication of this article is financed by CNRS-INSU.

\section{References}

Abnizova, A., Siemens, J., Langer, M., and Boike J.: Small ponds with major impact: The relevance of ponds and lakes in permafrost landscapes to carbon dioxide emissions, Global Biogeochem. Cy., 26, GB2041, doi:10.1029/2011GB004237, 2012.

Alekin, Î. À.: Basics of hydrochemistry, Hydrometeoizdat, Leningrad, pp. 296, 1953 (in Russian).

Alexeev, S. V., Alexeeva, L. P., Shouakar-Stash, O., and Frape, S. K.: Geochemical and isotope features of brines of the Siberian platform, in: Water-Rock Interaction, edited by: Wanty, R. B. and Seal, R. R., 333-336, Taylor and Francis, Philadelphia, Pa., 2004.

Antoniades, D., Douglas, M. S. V., and Smol, J. P.: The physical and chemical limnology of 24 ponds and one lake from Isachsen, Ellef Ringnes Island, Int. Rev. Hydrobiol., 88, 519-538, 2003.

Audry, S., Pokrovsky, O. S., Shirokova, L. S., Kirpotin, S. N., and Dupré, B.: Organic matter mineralization and trace element post-depositional redistribution in Western Siberia thermokarst lake sediments, Biogeosciences, 8, 3341-3358, doi:10.5194/bg8-3341-2011, 2011.

Boike, J., Kattenstroth, B., Abramova, K., Bornemann, N., Chetverova, A., Fedorova, I., Fröb, K., Grigoriev, M., Grüber, M., Kutzbach, L., Langer, M., Minke, M., Muster, S., Piel, K., Pfeiffer, E.-M., Stoof, G., Westermann, S., Wischnewski, K., Wille, C., and Hubberten, H.-W.: Baseline characteristics of climate, permafrost and land cover from a new permafrost observatory in the Lena River Delta, Siberia (1998-2011), Biogeosciences, 10, 2105-2128, doi:10.5194/bg-10-2105-2013, 2013.

Bryksina, N. A. and Kirpotin S. N.: Landscape-space analysis of change of thermokarst lakes areas and numbers in the permafrost zone of West Siberia, Tomsk State University Journal of Biology, 4, 185-194, 2012 (in Russian).

Bryksina, N. A., Polishchuk, Y. M., and Polishchuk, V. Y.: Study of the relationship between climatic and thermokarst processes in continuous and discontinuous permafrost zones of Western
Siberia, Vestnik Yugorskogo gosudarstvennogo universiteta, 3, 3-12, 2009 (in Russian).

Bouchard, F., Pienitz, R., Ortiz, J. D., Francus, P., and Laurion I.: Palaeolimnological conditions inferred from fossil diatom assemblages and derivative spectral properties of sediments in thermokarst ponds of subarctic Quebec, Canada, Boreas, 42, 575-595, doi:10.1111/bor.12000, 2012.

Brown, J., Ferrians, O. J. J., Heginbottom, J. A., Melnikov, E. S.: International Permafrost Association Circum Arctic Map of Permafrost and Ground Ice Conditions, US Geological Survey CircumPacific Map Series, Map CP 45, Scale 1:10,000,000, Washington, DC, USA, 1997.

Burn, C. R. and Smith, M. W.: Development of thermokarst lakes during the Holocene at sites near Mayo, Yukon territory, Permafrost Periglacial., 1, 161-175, 1990.

Callaghan, T. V., Kirpotin, S. N., Werkman, B., Vorobyev, S. N., Brown, I., and Lukyantsev, V. V.: Investigation of Contrasting Climate Impact on Vegetation and Landscape Processes in Forest Tundra and Taiga of the Western Siberian Plain as a Basis for the Opening up of the North, in: Exploration of the North: Traditions and Challenge of Time, Tomsk, 62-63, 1999.

Chen, M., Rowland, J. C., Wilson, C. J., Altmann, G. L., and Brumby, S. P.: The importance of natural variability in lake areas on the detection of permafrost degradation: A case study in the Yukon Flats, Alaska, Permafrost Periglac., 24, 224-240, 2013.

Collins, A. G.: Geochemistry of Oilfield Brines, 496 pp., Elsevier, New York, 1975.

Cory, R. M., McKnight, D. M., Chin, Y.-P., Miller, P., and Jaros, C. L.: Chemical characteristics of fulvic acids from Arctic surface waters: Micorbial contributions and photochemical transformations, J. Geophys. Res., 112, G04S51, doi:10.1029/2006JG000343, 2007.

Côté, G., Pienitz, R., Velle, G., and Wang X.: Impact of geese on the limnology of lakes and ponds from Bylot Island (Nunavut, Canada), Int. Rev. Hydrobiol., 95, 105-129, 2010.

Dneprovskaya, V. P., Bryksina, N. A., and Polishchuk, Yu. M.: Study of thermokarst changes in discontinuous zone of West Siberian permafrost based on space images, Issledovanie Zemli iz Kosmosa (Earth Study from Space), 4, 88-96, 2009 (in Russian).

Domaniczkii, A. P., Doubrovina, R. G., and Isaeva, A. I.: The rivers and lakes of the Soviet Union, Gidrometeorologicheskoe izdatelstvo, Leningrad, pp. 106, 1971 (in Russian).

Duff, K. E., Laing, T. E., Smol, J. P., and Lean, D. R. S.: Limnological characteristics of lakes located across arctic treeline in northern Russia, Hydrobiologia, 391, 205-222, 1999.

Dugan, H. A., Lamoureux, S. F., Lewis, T., and Lafrenière, M. J.: The impact of permafrost disturbances and sediment loading on the limnological characteristics of two high Arctic lakes, Permafrost Periglac., 23, 119-126, 2012.

Frey, K. E., Siegel, D. I., and Smith, L. C.: Geochemistry of west Siberian streams and their potential response to permafrost degradation, Water Resour. Res., 43, W03406, doi:10.1029/2006WR004902, 2007.

Granat, L.: On the relation between $\mathrm{pH}$ and the chemical composition in atmospheric precipitation, Tellus, 6, 550-560, 1972.

Grosse, G., Jones, B., Arp, C.: Thermokarst lakes, drainage, and drained basins, in: Treatise on Geomorphology, edited by: Shroder, J. (Editor in Chief), Giardino, R., and Harbor, J., Aca- 
demic Press, San Diego, CA, Glacial and Periglacial Geomorphology, 8, 325-353, 2013.

Helms, J. R., Stubbins, A., Ritchie, J. D., Minor, E. C., Kieber, D. J., and Mopper, K.: Absorption spectral slopes and slope ratios as indicators of molecular weight, source, and photobleaching of chromophoric dissolved organic matter, Limnol Oceanogr., 53, 955-969, 2008.

Ivanov, K. E. and Novikov, S. M.: Mires of Western Siberia: their structure and hydrological regime, Hydrometeoizdat, Leningrad, pp. 448, 1976 (in Russian).

Jantze, E. J., Lyon, S. W., and Destouni, G.: Subsurface release and transport of dissolved carbon in a discontinuous permafrost region, Hydrol. Earth Syst. Sci., 17, 3827-3839, doi:10.5194/hess17-3827-2013, 2013.

Karlsson, J. M., Lyon, S. W., and Destouni, G.: Thermokarts lake, hydrological flow and water balance indicators of permafrost change in Western Siberia, J. Hydrol., 464-465, 459-466, 2012.

Karlsson, J. M., Lyon, S. W., and Destouni, G.: Temporal behavior of lake size-distribution in a thawing permafrost landscape in Northwestern Siberia, Remote Sens., 6, 621-636, doi:10.3390/rs6010621, 2014.

Kirpotin, S., Vorobjev, S., Chmyz, V., Guzynin, T., Skoblikov, S., and Yakovlev, A.: Structure and dynamics of vegetative cover of palsas in Nadym-Pur interfluve of West Siberia plain, Bot. J., 80, 29-39, 1995 (in Russian).

Kirpotin, S., Berezin, A., Bazanov, V., Polishchuk, Yu., Vorobiov, S., Mironycheva-Tokoreva, N., Kosykh, N., Volkova, I., Dupré, B., Pokrovsky, O., Kouraev, A., Zakharova, E., Shirokova, L., Morgand, N., Biancamaria, S., Viers, J., and Kolmakova, M.: Western Siberia wetlands as indicator and regulator of climate change on the global scale, Int. J. Environ. Stud., 66, 409-421, 2009a.

Kirpotin, S., Polishchuk, Y., and Bryksina, N.: Abrupt changes of thermokarst lakes in Western Siberia: impacts of climatic warming on permafrost melting, Int. J. Environ. Stud., 66, 423-431, $2009 b$.

Kirpotin, S., Polishchuk, Y., Bryksina, N., Sugaipova, A., Kouraev, A., Zakharova, E., Pokrovsky, O. S., Shirokova, L., Kolmakova, M., Manassypov, R., and Dupré, B.: West Siberian palsa peatlands: Distribution, typology, cyclic development, present day climate-driven changes, seasonal hydrology and impact on $\mathrm{CO}_{2}$ cycle, Int. J. Environ. Stud., 68, 603-623, 2011.

Kirpotin, S. N. and Vorobiov, S. N.: The Natural Dynamics of SubArctic Landscapes in the West Siberian Plain as Indicator of Global Changes of Climate. Vegetation and Climate, in: 42nd annual Symposium of the IAVS - 1st/ ed., Vitoria-Gazteiz: Servico Central de Publicaciones del Gobierno Vasco, 74, 1999.

Kirpotin, S. N., Blyakharchuk, T. A., and Vorobiov, S. N.: Dynamics of palsas of the West Siberian Plain as an indicator of global climate change, Vestnik of Tomsk State University, 123-134, 2003 (in Russian).

Kirpotin, S. N., Naumov, A. V., Vorobiov, S. N., MironychevaTokareva, N. P., Kosykh, N. P., Lapshina, E. D., Marquand, J., Kulizhski, S. P., and Bleuten, W.: Western-Siberian Peatlands: Indicators of Climate Change and Their Role in Global Carbon Balance, in: Climate Change and Terrestrial Carbon Sequestration in Central Asia, edited by: Lal, R., Suleimenov, M., Stewart, B. A, Hansen, D. O., and Doraiswamy, P., Taylor and Francis, Amsterdam, 453-472, 2007.
Kirpotin, S. N., Polishchuk, Yu. M., and Bryksina, N. A.: Thermokarst lakes square dynamics of West Siberian continuous and discontinuous permafrost under impact of global warming, Vestnik of Tomsk State University, 311, 185-189, 2008 (in Russian).

Kling, G. W., O'Brien, W. J., Miller, M. C., and Hershey, A. E.: The biogeochemistry and zoogeography of lakes and rivers in arctic Alaska, Hydrobiologia, 240, 1-14, 1992.

Kohler, S., Buffam, I., Jonsson, A., and Bishop, K.: Photochemical and microbial processing of stream and soil water dissolved organic matter in a boreal forested catchment in northern Sweden, Aquat. Sci., 64, 269-281, 2002.

Kokelj, S. V. and Jorgenson, M. T.: Advances in Thermokarst Research, Permafrost Periglac., 24, 108-119, doi:10.1002/ppp.1779, 2013.

Kokelj, S. V., Jenkins, R. E., Milburn, D., Burn, C. R., and Snow, N.: The influence of thermokarst disturbance on the water quality of small upland lakes, Mackensie Delta Region, Northwest Territories, Canada, Permafrost Periglac., 16, 343-353, 2005.

Kokelj, S. V., Zajdlik, B., and Thompson, M. S.: The impacts of thawing permafrost on the chemistry of lakes across the subarctic boreal-tundra transition, Mackenzie Delta region, Canada, Permafrost Periglac., 20, 185-199, 2009.

Kozlov, S. A.: Evaluation of stability of the geological environment at offshore fields hydrocarbons in the Arctic, Elektronnii nauchnii jurnal "Neftegazovoe delo", 3, 15-24, 2005 (in Russian).

Kravtsova, V. I. and Bystrova, A. G.: Changes in thermokarst lake size in different regions of Russia for last 30 years, Kriosfera Zemli, 2, 16-26, 2009 (in Russian).

Kumke, T., Ksenofontova, M., Pestryakova, L., Nazarova, L., and Hubberten, H.-W.: Limnological characteristics of lakes in the lowlands of Central Yakutia, Russia, J. Limnol., 66, 40-53, 2007.

Laurion, I., Ventura, M., Catalan, J., Psenner, R., and Sommaruga, R.: Attenuation of ultraviolet radiation in mountain lakes: Factors controlling the among- and within-lake variability, Limnol. Oceanogr., 45, 1274-1288, 2000.

Laurion, I., Vincent, W. F., MacIntyre, S., Retamal, L., Dupont, C., Francus, P., and Pienitz, R.: Variability in greenhouse gas emissions from permafrost thaw ponds, Limnol. Oceanogr., 55, 115133, 2010.

Leonova, G. A.: Biogeochemical indicators of aquatic ecosystem pollution by heavy metals, Water Resour., 31, 195-202, 2004.

Leonova, G. A., Anoshin, G. N., and Bychinskii, V. A.: Anthropogenic chemical transformation of aquatic ecosystems: Biogeochemical problems, Geochem. Int., 43, 153-167, 2005.

Lim, D. S. S., Douglas, M. S. V., Smol, J. P., and Lean, D. R. S.: Physical and chemical limnological characteristics of 38 lakes and ponds on Bathurst Island, Nunavut, Canadian High Arctic, Int. Rev. Hydrobiol., 86, 1-22, 2001.

Lim, D. S. S., Douglas, M. S. V., and Smol, J. P.: Limnology of 46 lakes and ponds on Banks Island, N.W.T., Canadian Arctic Archipelago, Hydrobiologia, 545, 11-32, 2005.

Manasypov, R. M., Kirpotin, S. N., Pokrovsky, O. S., and Shirokova, L. S.: Features of the elemental composition of lake waters and macrophytes in thermokarst subarctic ecosystems of West Siberia, Tomsk State University Journal of Biology, 3, 186198, 2012 (in Russian).

Matthews, J. A., Dahl, S.-O., Berrisford, M. S., and Nesje, A.: Cyclic Development and Thermokarstic Degradation in the Mid- 
Alpine Zone at Leirpullan, Dovrefjell, Southern Norway, Permafrost Periglac., 8, 107-122, 1997.

Michelutti, N., Douglas, M. S. V., Lean, D. R. S., and Smol, J. P.: Physical and chemical limnology of 34 ultra-oligotrophic lakes and ponds near Wanniatt Bay, Victoria Island, Arctic Canada, Hydrobiologia, 482, 1-13, 2002a.

Michelutti, N., Douglas, M. S. V., Muir, D. C. G., Wang, X., and Smol, J. P.: Limnological characteristics of 38 lakes and ponds on Axel Heiberg Island, High Arctic Canada, Int. Rev. Hydrobiol., 87, 385-399, 2002b.

Moskovchenko, D. V.: Geochemistry of landscapes of the north of West Siberian Plain: structur-functional organization of matter of geosystems and problems ekodiagnostic, Aftoreferat dis.... d-ra geogr. nauk., Saint-Petersburg, 33 pp., 2010 (in Russian).

Moskovchenko, D. V. and Babushkin, A. G.: Peculiarities of formation of chemical composition of snow waters (on example of Khanty-Mansi autonomous district), Kriosfera Zemli, 1, 71-81, 2012 (in Russian).

Muldiyarov, E. Y., Lapshina, E. D., Kremenetskiy, K., and Perevodchikov, E. V.: History of development and structure of the peat layer of bogs of northern taiga of west Siberia, in: West Siberian Peatlands and Carbon Cycle: Past and Present, edited by: Vasiliev, S. V., Titlyanova, A. A., and Velichko, A. A., Noyabrsk, 41-44, 2001 (in Russian).

Pienitz, R., Smol, J. P., and Lean, D. R. S.: Physical and chemical limnology of 24 lakes located between Yelloknife and Contwoyto Lake, Northwest Territories (Canada), Can. J. Fish. Aquat. Sci., 54, 347-358, 1997a.

Pienitz, R., Smol, J. P., and Lean, D. R. S.: Physical and chemical limnology of 59 lakes located between the southern Yukon and the Tuktoyaktuk Peninsula, Northwest Territories (Canada), Can. J. Fish. Aquat. Sci., 54, 330-346, 1997 b.

Pokrovsky, O. S., Viers, J., Shirokova, L. S., Shevchenko, V. P., Filipov, A. S., and Dupré, B.: Dissolved, suspended, and colloidal fluxes of organic carbon, major and trace elements in the Severnaya Dvina River and its tributary, Chem. Geol., 273, 136-149, 2010.

Pokrovsky, O. S., Shirokova, L. S., Kirpotin, S. N., Audry, S., Viers, J., and Dupré, B.: Effect of permafrost thawing on organic carbon and trace element colloidal speciation in the thermokarst lakes of western Siberia, Biogeosciences, 8, 565-583, doi:10.5194/bg-8565-2011, 2011.

Pokrovsky, O. S., Shirokova, L. S., Zabelina, S. A., Vorobieva, T. Y., Moreva, O. Yu., Klimov, S. I., Chupakov, A., Shorina, N. V., Kokryatskaya, N. M., Audry, S., Viers, J., Zouten, C., and Freydier, R.: Size fractionation of trace elements in a seasonally stratified boreal lake: control of organic matter and iron colloids, Aquat. Geochem., 18, 115-139, 2012.

Pokrovsky, O. S., Shirokova, L. S., Kirpotin, S. N., Kulizhsky, S. P., and Vorobiev, S. N.: Impact of western Siberia heat wave 2012 on greenhouse gases and trace metal concentration in thaw lakes of discontinuous permafrost zone, Biogeosciences, 10, 5349-5365, doi:10.5194/bg-10-5349-2013, 2013.

Pokrovsky, O. S., Shirokova, L. S., and Kirpotin, S. N.: Biogeochemistry of Thermokarst Lakes of Western Siberia, Nova Science Publ. Inc., NY, 163 pp., 2014.

Polishchuk, Y., Kirpotin, S., and Bryksina, N.: Remote study of thermokarst lakes dynamics in west-Siberian permafrost, in: Permafrost: Distribution, Composition and Impacts on Infrastructure and Ecosystems, edited by: Pokrovsky, O. S., Nova Science Publishers, Inc., New York, 173-204, 2014.

Rautio, M., Dufresne, F., Laurion, I., Bonilla, S., Vincent, W. F., and Christoffersen, K.: Shallow freshwater ecosystems of the circumpolar Arctic, Ecoscience, 18, 204-222, 2011.

Roach, J., Griffith, B., Verbyla, D., and Jones, J.: Mechanisms influencing changes in lake area in Alaskan boreal forest, Glob. Change Biol., 17, 2567-2583, 2011.

Rikhter, G. D.: Western Siberia, Acad Sci. USSR Press, Moscow, 188 pp., 1963 (in Russian).

Rühland, K. and Smol, J. P.: Limnological characteristics of 70 lakes spanning Arctic treeline from Coronation Gulf to Great Slave lake in the Central Northwest territories, Canada, Int. Rev. Hydrobiol., 83, 183-203, 1998.

Savchenko, N. V.: Nature of lakes in subarctic of West Siberia, Geografiya i prirodnie resursy, 1, 85-92, 1992 (in Russian).

Savichev, O. G.: Condition of ionic runoff formation in middle $\mathrm{Ob}$ river basin, Izvestiya Tomskogo politekhnicheskogo universiteta, 308, 54-58, 2005 (in Russian).

Savichev, O. G., Kolesnichenko, L. G., and Saifulina, E. V.: The ecologo-geochemical state of water bodies in the Taz-Yenisei interfluves, Geografiya i prirodnie resursy, 4, 45-49, 2011 (in Russian).

Shirokova, L. S., Pokrovsky, O. S., Kirpotin, S. N., and Dupré, B.: Heterotrophic bacterio-plankton in thawed lakes of the northern part of Western Siberia controls the $\mathrm{CO}_{2}$ flux to the atmosphere, Int. J. Environ. Stud., 66, 433-445, 2009.

Shirokova, L. S., Pokrovsky, O. S., Kirpotin, S. N., Desmukh, C., Pokrovsky, B. G., Audry, S., and Viers, J.: Biogeochemistry of organic carbon, $\mathrm{CO}_{2}, \mathrm{CH}_{4}$, and trace elements in thermokarst water bodies in discontinuous permafrost zones of Western Siberia, Biogeochemistry, 113, 573-593, 2013.

Shotyk, W., Blaser, P., Grünig, A., and Cheburkin, A. K.: A new approach for quantifying cumulative, anthropogenic, atmospheric lead deposition using peat cores from bogs: $\mathrm{Pb}$ in eight Swiss peat bog profiles, Sci. Total Environ., 249, 281-295, 2000.

Sollid, J. L. and Sorbel, L.: Palsa bogs as a climate indicator - examples from Doverfjell, Southern Norway, Ambio, 27, 287-291, 1998.

Solovieva, N., Jones, V. J., Nazarova, L., Brooks, S. J., Birks, H. J. B., Grytnes, J.-A., Appleby, P. G., Kauppila, T., Kondratenok, B., Renberg, I., and Ponomarev, V.: Palaeolimnological evidence for recent climatic change in lakes from the northern Urals, arctic Russia, J. Paleolimnol., 33, 463-482, 2005.

Summers, R. S., Cornel, P. K., and Roberts, P. V.: Molecular size distribution and spectroscopic characterization of humic substances, Sci. Total Environ., 62, 27-37, 1987.

Tank, S. E., Esslein, R. H. H., and Esack, L. F. W. L.: Northern delta lakes as summertime $\mathrm{CO}_{2}$ absorbers within the arctic landscape, Ecosystems, 12, 144-157, 2009.

Tank, S. E., Lesack, L. F. W., Gareis, J. A. L., Osburn, C. L., and Hesslein, R. H.: Multiple tracers demonstrate distinct sources of dissolved organic matter to lakes of the Mackenzie Delta, western Canadian Arctic, Limnol. Oceanogr., 56, 1297-1309, 2011.

Thorn, K. A., Younger, S. J., and Cox, L. G.: Order of functionality loss during photodegradation of aquatic humic substances. J. Environ. Quality, 39, 1416-1428, 2010.

Tomberg, I. V., Firsova, A. D., Sorokovikova, L. M., Sezko, N. P., Pogodaeva, T. V., and Khodzher, Ò. V.: Water chemistry and phy- 
toplankton in the Gyda Bay (Kara sea), Kriosfera Zemli, 4, 9092, 2011 (in Russian).

Vasyukova, E. V., Pokrovsky, O. S., Viers, J., Oliva, P., Dupré, B., Martin, F., and Candaudap, F.: Trace elements in organic- and iron-rich surficial fluids of the boreal zone: Assessing colloidal forms via dialysis and ultrafiltration, Geochim. Cosmochim. Ac., 74, 449-468, 2010.

Vincent, W. F. and Pienitz, R.: Sensitivity of high latitude freshwater ecosystems to global change: temperature and solar ultraviolet radiation, Geoscience Canada 23, 231-236, 1996.

Walter, K. M., Zimov, S. A., Chanton, J. P., Verbyla, D., and Chapin III, F. S.: Methane bubbling from Siberian thaw lakes as a positive feedback to climate warming, Nature, 443, 71-75, 2006.

Walter, K. M., Chanton, J. P., Chapin III, F. S., Schuur, E. A. G., and Zimov, S. A.: Methane production and bubble emissions from arctic lakes: Isotopic implications for source pathways and ages, J. Geophys. Res., 113, G00A08, doi:10.1029/2007JG000569, 2008.
Walter Anthony, K. M., Anthony, P., Grosse, G., and Chanton, J.: Geologic methane seeps along boundaries of Arctic permafrost thaw and melting glaciers, Nat. Geosci., 5, 419-426, doi:10.1038/ngeo1480, 2012.

Weishaar, J. L., Aiken, G. R., Bergamaschi, B. A., Fram, M. S., Fugii, R., and Mopper, K.: Evaluation of specific ultraviolet absorbance as an indicator of the chemical composition and reactivity of dissolved organic carbon, Environ. Sci. Technol., 37, 47024708, 2003.

Wetterich, S., Herzschuh, U., Meyer, H., Pestryakova, L., Plessen, B., Lopez, C. M. L., and Schirrmeister, L.: Evaporation effects as reflected in freshwaters and ostracod calcite from modern environments in Central and Northeast Yakutia (East Siberia, Russia), Hydrobiologia, 614, 171-195, 2008. 